\title{
El humor gráfico en la prensa sefardí: el caso de las portadas de El Ĵguetón de Constantinopla*
}

\author{
Aitor García Moreno ** \\ ILC - CSIC, Madrid
}

\begin{abstract}
El presente trabajo se dedica a la edición, descripción y análisis de un corpus de 53 portadas del periódico humorístico El Ĵguetón de Constantinopla, caracterizadas por el recurso al humor gráfico, hecho casi único en la prensa sefardí del momento. Tanto las imágenes (fotografías, caricaturas, etc.) como los textos que las acompañan están llenos de valiosísima información sobre la vida diaria de la comunidad sefardí de Turquía en el período de entreguerras, y nos muestran de primera mano el proceso de occidentalización, modernización y secularización de los sefardíes de Turquía y los Balcanes.
\end{abstract}

PALABRAS CLAVE: prensa; Turquía; sefardíes; humor; caricaturas; judeoespañol.

Graphic Humour in the Sephardic Press: The Covers of $E_{L} \hat{J}_{\text {UGuetón of Constantinople. }-~}$ This article focuses on the critical edition, description and analysis of 53 covers of the humorous newspaper El Ĵjuetón of Constantinople. They are characterized by the rare use of graphic humour in contemporary Sephardic press. Both images (photographs, cartoons, etc.) and surrounding texts contain invaluable information about the daily life of Sephardic communities in Turkey during the interwar period. In addition, they chronicle the process of westernization, modernization and secularization of the Sephardic Jews of Turkey and the Balkans.

KeYwords: Press; Turkey; Sephardic Jews; Humour; Cartoons; Judeo-Spanish.

El Juguetón, «Ĵournal humorístico que aparece cada semana, el día que tiene gana el director»-como rezaba en cierto momento su cabecera-, fue fundado en 1908 por Eliyá Carmona, a las pocas semanas de la desaparición de la censura en el Imperio otomano, tras la revolución de los Jóvenes Turcos. Así lo afirman tanto el propio Carmona en su autobiografía ${ }^{1}$, como las cabeceras analizadas en

* El presente trabajo ha sido realizado dentro del proyecto «Sefarad, siglo XXI (2009-2011): Edición y estudio filológico de textos sefardíes» (FF12009-10672).

**aitor.garcia@cchs.csic.es

${ }^{1}$ Eliyá CARmona, Cómo nació Elia Carmona: cómo se engrandeció y cómo se hiźo director del Juguetón, pág. 93; apud Robyn K. Loewenthal, Elia Carmona's Autobiography: JudeoSpanish Popular Press and Novel Publishing Milieu in Constantinople, Ottoman Empire, Circa 1860-1932, 2 vols. (Ph. D. Diss., University of Nebraska, 1984), pág. 354. 
este estudio, que señalan que el periódico fue fundado en el año 5668 [= 19071908]; si bien es verdad que otras fuentes dan como año de inicio $1909^{2}$. Y es que el primer número apareció el 2 de ḥešván de 5669 (esto es, el martes 26 de octubre de 1908) ${ }^{3}$, pocas semanas después del año nuevo judío; aunque el acto jurídico-administrativo de la fundación en sí -al que se refiere Carmona en sus memorias diciendo que se produjo «15 días después de la proclamación de la constitución»-, bien podría haber tenido lugar antes del cambio de año.

La idea -en cualquier caso-, parece ser que le rondaba la cabeza desde hacía casi cinco años, tal y como el propio Carmona relata ${ }^{4}$ :

En los primeros días que había retornado de Eg̀ipto yo era asentado en el caśino de Aristidi de Ortakioy, acompañado de los amigos Se. J̀ac Ojalvo, Se. Marco Castoriano y un otro amigo que no me acodro.

Hablando del Eg̀ipto y de la libertad de la prensa de allí ${ }^{5}$ yo dije que si al Dio él allega a ver en Costán presa libre, yo iba fundar un jornal de reír y lo iba a llamar El Juguetón ${ }^{6}$.

Aunque entiendo que nada podía hacerle imaginar aquel martes de 1908 en que salió a la calle el primer número, que habría de convertirse en una de las

${ }^{2}$ Vid. Gad Nassi, Jewish Journalism and Printing Houses in the Otoman Empire and Modern Turkey (Istambul 2001), pág. 34.

${ }^{3}$ Agradezco a la Dra. Aldina Quintana que me haya proporcionado la copia digital de dicho número.

${ }^{4}$ Para la presentación de ejemplos o citas en judeoespañol, sigo en lo fundamental el sistema de Sefarad que es el de la Escuela Española de Filología Sefardí expuesto en Iacob M. Hassán, «Transcripción normalizada de textos judeoespañoles», Estudios Sefardíes 1 (1978), págs. 147150, con las ligeras enmiendas propuestas en Aitor GARCía Moreno, Relatos del pueblo ladinán: Me'am lo'eź de Éxodo (Madrid 2004), págs. 31-33. No incluido allí, se advierte ahora que la distribución en nuestra edición de <-r-> y <-rr-> intervocálicas sigue las reglas de la ortografía normativa del español estándar, independientemente de que la aljamía ofrezca siempre una sola

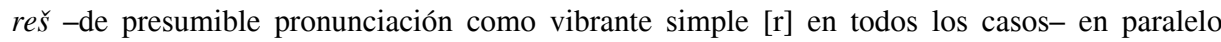
a nuestro proceder en la distribución de $\langle\mathrm{s}\rangle,\langle\mathrm{c}\rangle$ y $\langle\mathrm{z}\rangle$ según los casos, aun a sabiendas del generalizado seseo en judeoespañol. Para la presentación de los textos se sigue en general la composición del original. Introduzco entre corchetes aquellas letras que faltan por defectos en la impresión y pongo en mayúsculas los títulos que preceden a cada viñeta, y en redonda los pies de las ilustraciones, de acuerdo con la forma mayoritaria (que no unánime) en el original de utilizar letra hebrea merubá ' para títulos y raší para textos.

${ }^{5}$ Periódicos judeoespañoles publicados en aquel tiempo en Egipto fueron, por ejemplo, Miŝráyim (1904), La Vara (1905-1908) o La Luź (1907). Vid. Elena Romero, La creación literaria en lengua sefardí (Madrid 1992), págs. 188-189.

${ }^{6}$ Cf. Loewenthal, Autobiography, pág. 354. 
cabeceras más longevas del panorama periodístico judeoespañol; especialmente cuando otra media docena larga de periódicos sefardíes -incluidos varios de carácter humorístico- se lanzaban también a aprovechar la coyuntura política, viendo la luz en un muy corto período de tiempo (La Patria, La Yoź y El Burlón, también en 1908, y El Chuflete, La Luź, El Relámpago y El Judió, en 1909).

Este es el texto de la carta programática dirigida a los lectores que abría aquel primer número:

'A mis queridos 'y honorables lectores.

'Desde diez años la compośici[ó]n de mi 'flaca péndola pasa bajo vuestros o'jos, cuando con romanzos, cuando con his'torias y cuando con simples novelas; 'y en todas las ocaśiones yo remarco 'con alegría un benevolente recibo a mis 'escrituras.

'Este encorajamiento acordado de vu'estra parte, ajuuntado a_las demandas 'muy numerośas que me fueron hechas de par'te munchos amigos y conocidos, me hićieron 'decidar a empezar hoy la puḅlicación 'de este chico jornal humorístico que yo 'tengo el honor de preśentarvos y que se 'llamará El Juguetón.

'Este nombre bastará, creo, a_los lec'tores por entender lo_que él va contener: 'algunos artícolos humorísticos, roman'zos, jugos de familia, enigmas y todo 'lo_que haće divertir en familia.

'El Ĵguetón va ser escrito en un //1blinguaje muy fácil y muy corriente según 'haćemos también por nuestros romanzos. 'Y él será vendido por 10 parás.

'El Ĵuguetón aparecerá por horas u'na vez a_la semana y después de dos 'o tres meśes, lo más tadre, él apa'recerá dos većes a_la semana.

'Tengo la firme esperanza que, como 'en mis romanzos, el honorable púḅlico 'hará un buen recibo a mi chica gaćeta 'que de su parte no mancará a haćer todo 'su posible por renderla de día [e]n día 'más agradable. 'Eliyá R. Carmona»

Resulta difícil aventurar qué pudo ser determinante para que El Juguetón saliera semanalmente a las calles de Estambul durante la nada desdeñable cifra de 23 años, pues ni la propia factura del periódico (poco cuidada a tenor de las abundantes erratas y defectos de impresión que presentaba desde sus primeras líneas), ni su naturaleza esporádica, ni el hecho de ser -aparentemente- responsabilidad personal de Eliyá Carmona ${ }^{7}$, su «director-redactor» hasta su cierre un año antes de la muerte de este, le augurarían -a nuestros ojos- tanto éxito. Sin embargo, sin duda debieron de contribuir a ello las imágenes de su portada.

${ }^{7}$ En los primeros tiempos, Abraham Bejor David aparece como administrador del periódico. 
A la descripción y análisis de un corpus de 53 de dichas portadas (la primera del 20 de marzo de 1925 y la última del 5 de junio de 1931), se dedica el presente trabajo ${ }^{8}$.

\section{El CORPUS}

De las 53 portadas seleccionadas para nuestro estudio, sólo la primera es de $1925^{9}$; catorce pertenecen a $1927^{10}$; catorce más a $1928^{11}$; veintiuna corresponden a $1929^{12}$, dos a $1930^{13}$ y la última es de $1931^{14}$. Todas ellas comparten en lo fundamental un mismo esquema, con tres elementos bien diferenciados:

a) la cabecera de la parte superior, en la que junto al nombre del periódico se consignan otros datos como la fecha, el número, el precio (del ejemplar o de la suscripción), la periodicidad, la dirección de la redacción, etc.;

b) la imagen (ya sea una caricatura, un grabado, un fotomontaje o una fotografía sin más) de la zona central, precedida -por lo general, aunque no siempre- de un título, y seguida de los habituales subtítulos; y

c) uno o más anuncios publicitarios, situados en la parte inferior de la página, pero a veces también flanqueando la imagen.

Puesto que el análisis de los contenidos de dicha zona central (imagen, títulos y subtítulos) constituye el meollo de este estudio, describiremos primero muy brevemente los rasgos más significactivos de los otros dos elementos.

\footnotetext{
${ }^{8}$ Un importante número de las imágenes incluidas como anexo al final de este artículo (y otras no estudiadas aquí) aparecieron como ilustraciones del libro de Elena Romero, Y hubo luz y no fue tan buena: las coplas sefardíes de Purim y los tiempos modernos (Barcelona 2008). No obstante, decidimos reproducirlas nuevamente teniendo en cuenta 1) que son fundamentales para la comprensión de nuestro estudio; 2) que no para todas ellas se puede encontrar allí la edición del texto aljamiado que las acompaña, y 3 ) que en varios casos hemos localizado alguna que otra errata.

${ }^{9}$ Corresponde al núm. 3 del año XVII.

${ }^{10}$ De los núms. XIX/23, 25, 26, 30-39 y 41.

${ }^{11}$ De los núms. XIX/49, y XX/2, 4, 5, 11, 14-16, 18 у 22-26.

${ }^{12}$ De los núms. XX/41-43, 46, 47 y 50, y XXI:1, 5-7, 9, 10, 13, 15-19, 22, 26 у 27.

${ }^{13}$ De los núms. XXI/34 y 41 .

${ }^{14}$ Es el núm. XXIII/13.
} 


\subsection{Cabeceras}

Aun a sabiendas de lo desigual de la muestra, podemos señalar que hubo, al menos, cinco cabeceras distintas entre 1925 y 1931, y en las que se observa un proceso de progresiva complicación en cuanto al número de datos consignados:

La primera de ellas muestra ya tres secciones separadas entre sí por dos líneas horizontales. Por encima de la línea superior, apenas si se recoge (de derecha a izquierda) la información relativa al año del periódico (año diez y seteno), el día y la fecha según el calendario judío (viernes 24 adar 5685) y el número correspondiente (número 3). Entre las dos líneas, encontramos el título del periódico tanto en escritura árabe cúfica, como -debajo- el mismo en caracteres hebreos cuadrados (איל ג'וגיטון), que destacan por su cómica iluminación con una serie de figuritas ${ }^{15}$. A ambos lados del título y en disposición vertical, se lee: (dcha.) «Jornal humorístico fundado en 5668», e (izda.) «aparece cada semana el día que tiene gana el director». Debajo de la sección dedicada al título, a tres columnas y de derecha a izquierda, encontramos lo siguiente:

1]

$$
\begin{gathered}
\text { Abononamientos } \\
\text { Costán y provincias } \\
\text { un año, grušes 200; seš meśes, } 120 \\
\text { PRECIO DEL NÚMERO } 5 \text { GRUŠES }
\end{gathered}
$$

2]

$$
\begin{gathered}
\text { DIRECCIÓN Y ADMINISTRACIÓN } \\
\text { Istambul Sultán Hamid } \\
\text { Mesadet Han, nú. } 25 \\
\text { Director-Redactor Eliyá R. Carmona }
\end{gathered}
$$

$$
\begin{gathered}
\text { Abonamientos } \\
\text { por el estranjero } \\
\text { un año, francos } 30 \\
\text { seš meśes, } \quad " \quad 17
\end{gathered}
$$

\footnotetext{
${ }^{15}$ De derecha a izquierda: a la derecha del álef, un niño que hace volar una cometa; dentro de la misma álef inicial, una anciana sentada en una especie de mecedora; a ambos lados de la lámed, una pareja tomados de la mano; sobre la parte baja de la primera guímal se posa un búho; asomando tras la parte baja de la segunda guímal, un hombre; una pareja sentada a ambos lados de una mesa, reposa dentro de la tet, y tras la nun final se vislumbra una pareja bailando agarrados.
} 
La segunda cabecera destaca por añadir en la parte superior la fecha según el calendario cristiano; y así, en el «número 23» del «año diez y nueveno», a continuación de «martes 11 ab 5867» leemos «9 agosto 1927». Asimismo, el precio del ejemplar sale de la zona inferior de la cabecera para ocupar el ángulo superior izquierdo, casi en línea con el título del periódico en letras árabes.

Cabe señalar que dicha parte inferior de la cabecera con la información de contacto y precios de la suscripción (abonamientos), puede faltar por completo en ocasiones en beneficio del espacio para la ilustración ${ }^{16}$.

Tal vez por esa necesidad de espacio en la zona central, la tercera cabecera que tenemos supone una importante revolución visual en la disposición de la información hasta ahora recogida, si bien no cambian los contenidos. A partir del núm. XX/41 (del 4 de enero de 1929) en nuestra cala, en lugar del sistema de las tres columnas en la parte inferior de la cabecera, el título -cuya versión en aljamía árabe pasa a estar en letras latinas (EL CUGETON) ${ }^{17}-$ aparecera flanqueado por dos columnas de texto: a la derecha se concentrará la información sobre suscripción; y a la izquierda, la dirección de la redacción, el nombre del director y el precio del número. Debajo del título en aljamía hebrea, en un mismo renglón, los dos textos sobre la periodicidad y fecha de la fundación que veíamos antes.

Desgraciadamente, el cambio en la presentación se verá ensombrecido por tres errores en la composición de los textos, tanto en la palabra dirección (que aparece escrita sin reš, דייקסייון), como en la palabra número (escrita sin la primera vav, נמירו) -ambas del texto de la columna izquierda-, así como en la forma seš (en el original con trocamiento de šin y sámej, שיס) -en la columna derecha-, que sin duda afearon la renovadora propuesta.

Las variantes del cuarto tipo de portada son menores, pues continúa la disposición gráfica que acabamos de ver y tan sólo varía el contenido en lo que respecta a la dirección postal del periódico que aparece en la columna de la izquierda, ya que a partir del ejemplar que abre el año XXI (de 29 de marzo de 1927) pasa a ser:

${ }^{16}$. Así sucede en nuestro corpus, en los siguientes ejemplares: XIX/25, 26, 31, 32, 34, 35, 36 у $49 ; \mathrm{XX} / 2,11,15,16,24,25$ у 26.

${ }^{17}$ Aunque la sustitución en Turquía del alifato árabe por el abecedario latino fue aprobada el 24 de mayo de 1928, la obligatoriedad de su uso no tuvo efecto hasta el primero de enero de 1929. Recuérdese que en el alfabeto turco el grafema $<\mathrm{c}>$ representa el sonido [ŷ]. 


DiRECCIÓN
Y
ADMINISTRACIÓN
Istambul
Marpuchilar
Saliḥ Efendi Han nú. 17
Director redactor
ELIYA R. CARMONA
Precio del número, 5 gr.

Con el cambio de plancha parece aprovecharse para corregir algunas de las erratas que señalábamos antes: por ejemplo, desaparece el mencionado error en dirección, aunque se mantienen los otros dos.

Por último, el número 13 del año XXIII (de 5 de enero de 1931), nos ofrece una nueva variación más acorde con los tiempos. Ya sin erratas, se mantienen las dos columnas de texto que -como apuntábamos- flanqueaban el título en caracteres latinos y hebreos; pero ahora se añaden debajo del título tres recuadros de texto. El del centro, en aljamía hebraica, recoge las dos famosas frases sobre el carácter humorístico del periódico y su fecha de fundación, así como sobre la tan poco periódica periodicidad de la que hacía gala; en tanto que los de los lados -el uno en francés (dcha.) y el otro en turco (izda.), ambos en caracteres latinos- recogen también la orientación humorística del periódico, su fecha de fundación, el nombre de su director y el domicilio social. A saber:

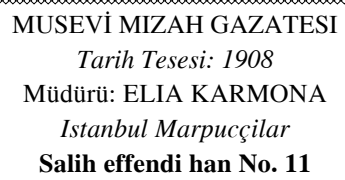

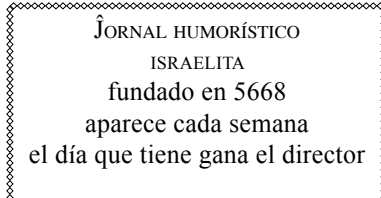

\section{Journal humoristique Israèlite fondé en 1908 \\ Directeur: ELIA CARMONA \\ Stamboul Marpoutchilar \\ Salih effendi han No. 11}

\subsection{Publicidad}

Como es bien sabido, junto con los ingresos provenientes de la venta de ejemplares, la prensa se mantenía (y mantiene) gracias a la presencia de publicidad.

En nuestro corpus, tan sólo tres de las portadas (núms. XIX/25, XXI/15 y XXI/17) destacan por carecer de anuncios, ocupando la ilustración la página entera.

Todas las demás, sin excepción, presentan al menos el reclamo publicitario de los «Grandes Magaśenes Láźaro Franco y hijos», situado siempre en la parte inferior de la primera página, salvo en el núm. XX/46 (del 15 de febrero de 1929) 
en que aparece dispuesto a la derecha de la imagen, con orientación vertical. El texto, que sufrió un par de modificaciones a lo largo de estos años -aparte de arrastrar de un número a otro diversos errores de composición sólo subsanados con la elaboración de un nuevo molde-, es mayoritariamente el siguiente ${ }^{18}$ :

\section{GRANDES MAGAŚENES LÁŹARO FRANCO Y HIJ̀OS}

Caśa fundada en 1860

$$
\text { Istambul Pera Gálata }
$$

Grande asortimento de artícolos de amoḅlamiento, como estufas, estores, perdés, mušamás, etc.

En el magaśen de Gálata se topa: bonetería, ling̀ería fina por damas, fajaduras, parfumería, robas y mantós ${ }^{19}$ etc.

ATANCIÓN

Consejo de no mercar nada antes de vis̀itar estos magaśenes porque todo lo que vende allí es bueno, hermośo, barato.

Por otro lado, en un par de ocasiones (núms. XX/25 y 26) encontramos el siguiente anuncio, situado a la izquierda de la imagen y con orientación vertical:

Haćed vuestros vestidos a precio de contán, a crédito al magaśen Čhic encima del magaśen Atlas de Istambul,

que más adelante (núms. XX/41, 42, 43, 46, 47 y 50, y XXI/1, 6 y 7) verá modificado su contenido para ofrecer una más cumplida información sobre la localización del almacén de marras:

Haćed vuestros vestidos a precio de contán, a crédito al magaśen Čhic de Istambul.

Sultán Hamam nú. 30.

${ }^{18}$ La referencia al almacén de Pera falta en el anuncio de la primera de nuestras portadas, cuyo texto es -en general- ligeramente diferente: «Grande asortimento de artícolos de amoḅlamiento, bonetería, ling̀ería fina por damas / fajaduras, parfumería, robas y mantós etc. / ATANCIÓN / No merquéš nada antes de vis̀itar estos magaśenes porque todo lo que vende allí es bueno, hermośo, barato». En cuanto al resto, cabe señalar que las palabras robas y mantós (línea 6 de nuestro ejemplo) de la serie de artículos que se anuncian para el almacén de Gálata desaparecen a partir del núm. XX/41; momento en que la última línea cambia a «Consejamos de no mercar nada antes de vis̀itar estos magaśenes porque todo lo que vende allí es bueno y barato».

${ }^{19}$ Prefiero la lectura mantós (del fr. sn. manteau 'abrigo') frente a la también posible manto, por aparecer coordinado en el texto con el galicismo robas (fr. robe 'vestido'). 
Aunque con menor frecuencia que los que acabamos de ver, podemos encontrar otros reclamos publicitarios con estrategias comerciales más agresivas, como este que encontramos en los núms. XX/41-43:

\section{NO VOS HAGÁŠ HִAĆINOS}

Guadradvos del frío y de la humiditá de los pieśes, que traen munchos males, y mercad con una lira šosones pretos, baǰicos y altos, con velures veritables, šosones fantaśís, griśos y beğes y otras colores, de las mijores marcas. Calzados de chicos fin grandes, escarpines turables y de la última moda. Lasticas de toda sorte de marca. Caśmires y tiftiques de Evropa a precios convenibles del Se. J̀ac Filiḅa, situado en Gálata, Šišané, Karakol nú. 44.

Del mismo comerciante de Gálata pero ahora con una muy diferente estrategia comercial, no menos directa que la anterior, son tanto el siguiente reclamo del núm. XXI/13:

\section{SABED LA VALOR}

Para que se diga que sabéš la valor de una cośa, es cuando se ve que mercáš una cośa sin engañar. Si queréš mercar toda sorte de calzados sin tener espanto de engañar, no tenéš que mercar del magaśen del Se. J̀ac Filiḅa, situado en Gálata, Šišané, Karakol nú. 44. En este magaśen se topa toda forma de calzados, escarpines de damas y de hombres los más garbośos y turables. Andad una vez y vos convenceréš;

como este último, del núm. XXI/16, en el que nuevamente varía el reclamo publicitario para promocionar sus productos, insistiendo ahora en las facilidades de pago.

\section{CON UNA LIRA PIŠÍN \\ y el resto con semanada.}

Puedéš tomar un calzado de hombre o mujer, si vaš directamente al magaśen del Se. J̀ac Filiḅa en Gálata,

Šišané, Karakol nú. 44 
En cualquier caso, la natural interdependencia de la prensa y la publicidad queda de manifiesto en el mensaje que desde la dirección del periódico se dirige a los lectores del núm. XXIII/13 (la última de nuestras portadas) anunciando una suspensión temporal en la actividad del periódico:

La grave maladía de nuestro director nos obliga a haćer aparecer el jornal de hoy en 4 hojas con muy pocos anuncios, en tomando también cong̀eto de nuestros honorables lectores por 15 días, onde salud habiendo no mos verán la cara;

mensaje donde parece intuirse una especie de disculpa también para con los anunciantes (fijos o no), tanto por el período de carencia como por no haber podido sacar a la luz más que la mitad de páginas. Algo que -pensando maliciosamente- nos llevaría a entender los textos del periódico como la excusa para poner publicidad -y no al revés-, y que bien podría ayudar a explicar la longevidad del semanario.

\section{HUMOR GRÁFICO}

Sea como fuere, parece innegable que la introducción de imágenes en las portadas de El Juguetón -no presentes en sus inicios ${ }^{20}-$, constituyó un gran acierto que se habría de mantener hasta el momento del cierre del periódico.

Desgraciadamente, aparte de constatar la existencia de las mismas desde, al menos, marzo de 1925 -fecha de la primera portada de nuestro corpus-, y que en el número 27 del primer año (de 26-3-1909) el periódico no había variado todavía su inicial fisonomía, no podemos concretar cuándo apareció la primera, ni aun si en los años 1925-26 -poco o nada representados en nuestra muestra-constituían un elemento fijo en todos los números, como se observa a partir de 1927.

Este hecho, prácticamente singular entre la prensa sefardí del momento si exceptuamos los dibujos que adornaban cabeceras como la de El Soitarí de Esmirna (1909-1913) o los grabados que, años antes, aparecían en la primera plana de El Manadero o La fuente de cencia para el pueblo (ca. 1855-1889) tal vez como parte de su estrategia misionera, estaba muy en boga entre los periódicos humorísticos turcoparlantes coetáneos y eran habituales en los que sin duda Carmona conoció en Egipto.

\footnotetext{
${ }^{20}$ Véase, por ejemplo, la imagen que se recoge en Loewenthal, Autobiography, pág. 433, correspondiente al núm. 24 del primer año, del jueves 17 de nisán de 5669 [= 8 de abril de 1909]. Curiosamente, en la misma línea de la cabecera de ese número puede leerse: «jornal humorístico que sale los miércoles».
} 
Esta perfecta integración en las corrientes del humorismo gráfico del momento se pone de manifiesto si tenemos en cuenta tres hechos fundamentales:

En primer lugar, la existencia en los primeros años de la revolución de los Jóvenes Turcos de, al menos, un par de talleres (İttihad ve Terakki Atelyesi y Soresco) que surtían de caricaturas a una gran variedad de periódicos ${ }^{21}$; si bien ignoramos si dicha venta se producía en exclusiva a una publicación en particular, o aun si el material suministrado por estos «mayoristas» incluía también los textos de los encabezamientos y subtítulos, o se limitaban sólo a la producción de diseños.

En segundo lugar, que el propio El Ĵuguetón publicaba en ocasiones ilustraciones o imágenes procedentes de otros periódicos turcos como el Papă̆an (1), el Arcadaş (31) o el Akbaba (51), como así lo hace constar; si bien nuevamente ignoramos si lo reproducido comprende todo el contenido o se refiere sólo a la imagen ${ }^{22}$.

$\mathrm{Y}$ en tercer lugar, que algunos de los más famosos caricaturistas turcos del momento publicaron también en El Juguetón, sin contar -claro está-, a los autores de las caricaturas compartidas con otras gacetas ${ }^{23}$.

Así sucede principalmente con Sezai Sayıcı, autor explícito de 3 de las caricaturas ${ }^{24}$ de nuestro corpus, y sobre todo con Ramiz Gökçe (1900-1953), uno de los más importantes del momento, con participación en una decena de publicaciones, y que firma 21 de las imágenes de portada de nuestra muestra ${ }^{25}$. Unas cantidades nada desdeñables si tenemos en cuenta que entre los dos dibujantes suman casi la mitad del número total de imágenes de la muestra, y que entre estas se incluyen dos grabados y cuatro fotografías.

Aunque en estos casos es de suponer que el autor proporcionaría todo el material (texto e imagen), tampoco es impensable que en más de un caso los

${ }^{21}$ Vid. Palmira Brummet, «Dogs, Women, Cholera and Other Menaces in the Streets: Cartoon Satire in the Ottoman Revolutionary Press», International Journal of Middle East Studies 27 (1995), págs. 433-460: 436.

${ }^{22}$ Los números entre paréntesis corresponden a los de cada viñeta en nuestro corpus, según consta en el anexo que aparece al final de estas páginas.

${ }^{23}$ Por ejemplo, Cemal Nadir Güler (1902-1947) parece el responsable de la viñeta tomada del Papağan, que citábamos antes.

${ }^{24}$ Se encuentran en los núms. XX/50, XXI/7 y XXIII/13, pero a juzgar por el tipo de dibujo, bien podría estar también detrás de otras tantas (núms. XX/41, XX/47 y XX/16).

${ }^{25}$ En concreto encontramos 14 (núms. XIX/23, 25, 32, 34, 36, 38 y 49, XX/2, 4, 14, 15, 18 y 22, y XXI/6) con una firma de sus comienzos -tal y como se aprecia entre los materiales disponibles en el sitio web de The Association of Cartoonists in Turkey (http://www. karikaturculerdernegi.org [consultado el 10-10-2009])- y 7 (núms. XX/24 у 25, у XXI/1, 5, 18,34 y 41) con la que sería la rúbrica más habitual en él en época posterior. Igualmente, bien podría ser el autor de las de los núms. XIX/35 y XXI/22, donde no se aprecia firma alguna, con ciertas semejanzas de estilo. 
subtítulos fueran responsabilidad de Eliyá Carmona (o algún colaborador suyo), y que las láminas pudieran haber sido hechas por encargo del director para ilustrar cierto chiste o parodia concretos.

De hecho, avalarían esta hipótesis tanto

a) el alto contenido «judaico» de algunos textos, con expresiones hebreas o juegos de palabras que difícilmente pueden deberse a traducción de lo servido por un no-judío; como

b) que algunas de las viñetas presenten cierta desconexión con el texto que las acompaña (o simplemente no aporten nada de interés y puedan intercambiarse por otras de otros números), o

c) que -frente a lo que sucedía precisamente en muchos de los periódicos humorísticos en turco de la época ${ }^{26}$, , no podamos reconocer un tipo caricaturesco netamente judío en ninguna de ellas.

Antes al contrario, y si no fuera porque podemos identificar a los autores de la gran mayoría de ellas, bien podríamos pensar que hubieran sido tomadas de cualquier periódico europeo de su tiempo, en lo que debemos interpretar como una manifestación más del carácter mundano y moderno de El Ĵuguetón que se trasluce en los propios temas tratados.

\subsection{Temática}

Muchos son los diferentes aspectos de la cambiante situación social y política del momento que aparecen reflejados en las portadas de nuestra muestra, y aun estos se combinan con frecuencia en una misma viñeta. Sin ánimo de ser exhaustivos en la enumeración de tipos y motivos, simplemente haremos una lista de los temas y subtemas más frecuentes agrupados en torno a tres ejes, igualmente interconectados.

- La igualación entre hombres y mujeres, con críticas a la mujer moderna y su incipiente proceso de emancipación, que es entendido por el varón como simple gusto por el solazamiento o la holgazanería $(3,13$ y 30$)$; falta de decoro (42) -especialmente en lo que toca a la forma de vestir $(1,2,4,32,33,34$ y 39)-; pérdida de respeto al marido $(18,51)$, y osadía al querer marcar el paso en las relaciones sexuales o personales dentro $(35,46,49)$ y fuera $(11,16$ y 37$)$

${ }^{26}$ Vid. Hatice BAYRAKTAR, Salamon und Rabeka: Judenstereotype in Karikaturen der türkischen Zeitschriften Akbaba, Karikatür und Milli İnkilap 1933-1945 (Berlin 2006). 
del matrimonio; salpicadas de alusiones constantes a su carácter interesado (7, 17, 18, 22, 28, 29, 36, 38, y posiblemente también la 41).

- La igualación entre clases sociales, con la referencia tópica a la servidumbre $(19,25$ y 44) y a los empleados respondones (8), que con frecuencia se codean sin distingos con sus jefes.

- La igualación cultural, presentando el gusto por lo moderno -ya se trate del baile $(14,15,26,31)$, el veraneo $(23,41,43$ y 45), inventos como el gramófono (50) o aun el uso de la escritura latina (27) - o el abandono de las tradiciones judías $(6,10,15,48$ y 52), como las dos caras de la moneda de la secularización y la transculturación de las comunidades sefardíes de la época.

En nuestras portadas, como en muchas de las coplas y textos poéticos sobre los tiempos modernos estudiadas por Elena Romero ${ }^{27}$, o en las letras de las canciones sobre la mujer moderna analizadas recientemente por Alberto Conejero $^{28}$, al que cito «[...] la voz enunciadora, que mantiene el punto de vista del varón, se sitúa siempre en un calculado punto intermedio entre la censura y el aplauso [...]». Y es que, al tiempo que se ridiculizan las nuevas modas en el vestir y se censuran las disparatadas y licenciosas costumbres, éstas son en buena medida publicitadas cuando no simplemente se saca partido de ellas.

Así, el presuntamente criticado descoco femenino en el vestir no es sino la excusa para presentar en portada mujeres cada vez más ligeras de ropa que sirvan de reclamo para la venta de ejemplares del periódico. De hecho, no deja de resultar sintomático que, en aquellas portadas donde la imagen lo inunda todo y ni siquiera viene acompañada de un texto, sean mujeres medio desnudas las que aparezcan en ellas (43 y sobre todo 45). ¿Se entendería si no, que junto a la supuesta burla de una mujer en paños menores se anuncie «ling̀eria fina para damas»?

En líneas generales, el responsable (o responsables) de las imágenes de portada no se casa con nada ni con nadie y a todos y a todo reparte por igual. Si tan peligrosa y perniciosa le resultara la liberación de la mujer, los maridos no aparecerían retratados como peleles complacientes; ni presentaría a horrendas novias de un matrimonio concertado, si buscara mantener a ultranza las tradiciones.

${ }^{27}$ Véanse, respectivamente, su libro $Y$ hubo $l u z$, y el artículo «Textos poéticos sobre la emancipación de la mujer sefardí», Sef 69, págs. 173-227 y 427-476.

${ }^{28}$ Alberto CONEJERO, «Cantos satíricos sobre la mujer moderna en Los cantes de la Trompeta y Los cantes de la Gata», ponencia invitada en la 4th International Conference on JudeoSpanish Studies (Salónica, 26-28 de octubre de 2008 [en prensa]). Véase también el artículo de Leonor CARRACEDo, «Canciones sefardíes del tiempo de Juan Chabás», en Dianium V (= Homenaje a Juan Chabás [1989]), págs. 231-257. 


\subsection{Recursos humorísticos}

Teniendo muy presente lo siempre subjetivo de toda consideración sobre lo que resulta o no humorístico, diremos que el efecto cómico y satírico de las portadas que hemos analizado descansa tanto en las imágenes como en los títulos y subtítulos que -salvo contadas excepciones- las acompañan.

En algunos casos, la propia viñeta muestra un estilo caricaturesco pretendidamente cómico per se. Así sucede -entiendo- en 3, 9, 12, 15, 18, 24, 48 y 53; algo que parece haberse buscado con la elección de la fotografía de 31 .

En otros, por el contrario, la imagen es prácticamente suprimible (o intercambiable por otra) y son los mini-diálogos de la pareja allí representada (matrimonios, novios, vecinos, amigos) lo que encierra el componente humorístico. Tal es el caso de 3, 5, 8, 10, 11, 16, 17, 22, 27, 28, 29, 36, 37, 38 у 47.

Normalmente, las viñetas apenas si recogen algún detalle (a veces mínimo) de la escena particular en que se inscriben los citados parlamentos, pero que resulta relevante para el entendimiento de la burla. Por ejemplo, el festival de pantorrillas y muslos de 1; el corto vestido de baño de 2; la actitud relajada de la esposa de 13; el apasionado beso de 19; el ridículo atuendo de la criada de 23, con sombrero en lugar de la habitual cofia; la pose despreocupada de la esposa de 30; la desnudez de la vecina de 32, las jóvenes de 33 o la recién casada de 34 , teniendo en cuenta que se encuentran en invierno; el escorzo huidizo de la esposa de 35; el escotado vestido de la mujer de 39; la amazona montada a horcajadas sobre el burro de 42; el alegre paseo de 44; el gimoteo del marido de 46; el libro de 49; la familia en torno al gramófono de 50; la altiva pose de la esposa de 51, o las dispares «bellezas» de 52.

Sin embargo -para mi gusto- las más curiosas resultan aquellas en las que es la contraposición entre texto e imagen la que genera el efecto más o menos risible, cuando seguramente, por separado, ninguno de los dos elementos sería tenido por demasiado cómico o evocador. Así sucede parcialmente en 4 , donde los mirones de la playa quedan asimilados a pececillos a punto de picar; en 6 , donde una joven en actitud oferente sostiene un racimo de uvas que -se nos dice- habrá de servir para adornar una cabañuela; en 14, donde las primeras manitas que hacen dos novios se nos presentan como el šeheheyanu ['palabra clave de la bendición que se pronuncia al degustar algo por vez primera'] del amor carnal; o en 48a, donde el ayuno ritual (ta 'anit) parece observarlo sólo una estilizada joven, obsesionada por la línea, mientras es escrutada por una muchedumbre de mujeres no precisamente delgadas ni bellas. 
Por otro lado, aparte de la relativa comicidad de las distintas anécdotas presentadas en los textos, ilustradas con mayor o menor acierto por las imágenes que las acompañan, y a veces derivadas de la chocante asociación de escenas cotidianas del todo prosaicas con la evocación de conceptos de profundo calado espiritual -como veíamos-, cabe resaltar el frecuente recurso a diversos juegos de palabras como motor de la hilaridad.

Así, en varias ocasiones $(11,35$ y 52$)$ la gracia se sustenta en la polisemia de la forma folar: nombre de cierto dulce típico de la festividad de Purim, que imita la horca destinada al Amán de la historia de Ester, pero también con el sentido de órgano sexual femenino ${ }^{29}$.

Algo parecido sucede con la expresión faćer šeheheyanu con el sentido de disfrutar de una primicia ${ }^{30}$, que veíamos antes para 14 ; y tal vez debamos entender un doble sentido picantón en la frase que acompaña a la imagen de 41 (Una demuaśel de Prinkipó que ya empezó a subirse encima del aśno por pasearse), entendiendo que se refiere a alguna interesada joven que no duda en aprovecharse de algún incauto (incluso dejando, llegado el caso, que este «se aproveche» de ella), para lograr que la invite durante sus vacaciones en estas islas del mar de Mármara en las que, hasta nuestros días, resulta típico dar paseos en burro para recorrerlas ${ }^{31}$.

Otras veces, parece ser la paronimia -como entre carré y caro, en 39- la que añade comicidad al texto; y aun otras -aunque tal vez se trate de algún tipo de deformación profesional por mi parte- la homografía aljamiada de formas como chames (tc. sn. çam) 'pinos' y james (tc. sn. cam) 'cristales' pero también 'ventanas' o 'lentes' -ambas escritas ג'אמיס-parece aportar una lectura extra en 3, si nos fijamos en que, encaramados a los pinos, hay unos mirones con prismáticos y catalejos espiando a las despreocupadas féminas.

${ }^{29}$ Joseph Nehama (Dictionnaire du Judéo-Espagnol [Madrid 1979], s.v. folár) lo define como «sucrerie affectant la forme d'une potence que l'on donne aux enfants à la fête de Pourim». Para otras descripciones más detalladas, véanse Michael MoLHo Usos y costumbres de los sefardíes de Salónica (Madrid 1950), p. 243, e Isaac Levy, Antología de liturgia judeoespañola (Jerusalem 1964-1977 [9 vols.]), vol. IV, pág. 154. El uso de folar en Bosnia como órgano sexual femenino lo recoge Max L. WAGNER («As influências recíprocas entre o Portugués e o Judeo-espanhol», Revista de Portugal 15/86 [1950], págs. 189-195: 195), citando a Julius SubaK («Zum Judenspanischen», Zeitschrift für Romanische Philologie XXX [1906], págs. 129-185:149).

${ }^{30}$ Cf. Nehama, Dictionnaire, s.v. šeejiyanu.

${ }^{31}$ Nuestra presuposición no parece demasiado desencaminada si tenemos en cuenta el texto de 37, en el que dos amigas departen sobre sus vacaciones en Prinkipó y una de ellas, que afirma primero estar acompañada por su amante, confiesa a continuación que todavía no ha decidido quién sea este, con lo que parece dar a entender que ha venido a ligar; o sea, a cazar. Asimismo, la idea de la playa como lugar de seducción, caza (o mejor dicho, pesca) queda también de manifiesto en el núm. 4, como ya hemos comentado. 


\section{ConCLuSión}

Sin ánimo de extenderme en el comentario particular de cada una de estas ilustraciones quisiera terminar esbozando otros aspectos (lingüísticos, pero también históricos o aun sociológicos) que podrían extraerse de tan jugoso material como el aquí presentado.

En el plano lingüístico, destacan tanto:

a) la variedad de registros documentables, compartiendo espacio en la misma página: con vívidas frases que recrean el judeoespañol coloquial (no vulgar, ojo) de la época, en los pasajes dialogados; junto a reclamos publicitarios más o menos logrados, o textos de corte informativo; como

b) la riqueza léxica que exhiben y para la que cabría llevar a cabo un estudio particular -sobre todo en lo tocante a los préstamos de otras lenguas- para intentar determinar si en efecto se trata de préstamos más o menos adaptados o a veces asistimos a simples ejemplos de cambio de código.

En el plano histórico -o casi mejor dicho intrahistórico- estos textos están llenos de valiosísima información sobre la vida diaria de la comunidad sefardí de Estambul en el período de entreguerras: desde el reflejo del proceso de deslocalización de la comunidad judía por distintos barrios de la ciudad, hasta datos sobre tiendas hoy desaparecidas o calles que han cambiado de nombre.

Y en el ámbito sociológico cultural, un nuevo ejemplo del tantas veces citado proceso de occidentalización, de modernización, de secularización, de los sefardíes de Turquía y los Balcanes, y que «equivale a la neutralización de los rasgos definitorios de las comunidades etno-religiosas $»^{32}$. Algo que se aprecia claramente en las portadas de El Ĵuguetón, para la sociedad judía, paralelamente a lo que otros periódicos turcos contemporáneos mostraban para la sociedad musulmana de su época, y sirviéndose unos y otros del recurso a un humor gráfico que no es el mismo, pero es igual.

Recibido: 25/09/2009

Aceptado: 18/ 01/2010

${ }^{32}$ Conejero, «Cantos». 


\section{ANEXO}

$\left.1^{33}\right]$ núm. XVII/3 (viernes 24 adar 5685 - [20/3/1925])

\section{(Del Papagán) EN QUÉ OCAŚIONES LAS DEMUAŚELES MOSTRAN LAS PIERNAS}

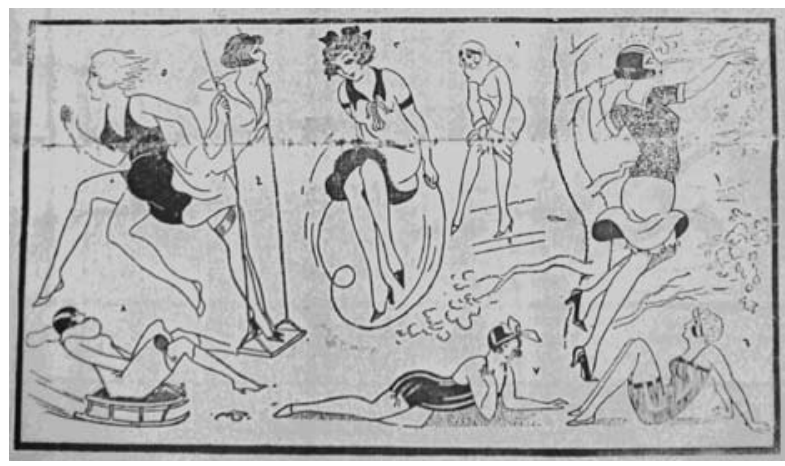

1.- Arrancando fruto en el árbole. 2.- Cuando se le afloja la jartier en la calle. 3.- En girando. 4.- En cunando. 5.- En corriendo en el espor.

6 y 7.- Cuando haćen en enverano baños de sol. 8.- Cuando se arreśbalan en invierno con el quiśac.

2] núm. XIX/23 (martes 11 ab 5687 - 9 agosto 1927)

\section{ENTRE DOS BAÑADERAS}

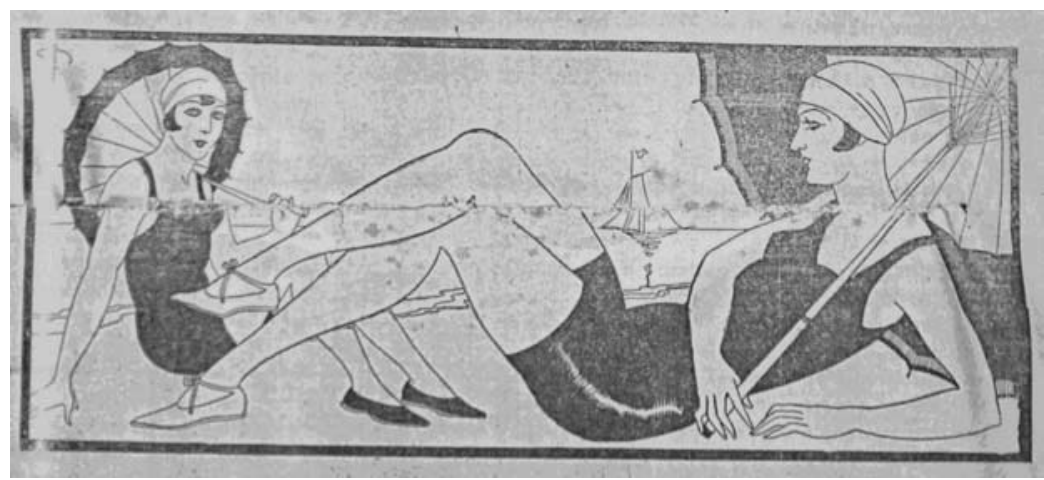

La una.- ¿De ónde mercates este hermośo vestido de baño de mar?

La otra.- Me lo hiće el otro año para el balo.

${ }^{33}$ Publicada en Romero, $Y$ hubo luz, pág. 114, no se incluye allí la referencia al periódico turco del que está sacada la ilustración «(Del Papagán)», ni el texto de la parte inferior. 
$3^{34}$ ] núm. XIX/25 (martes 25 ab 5687 - 23 agosto 1927)

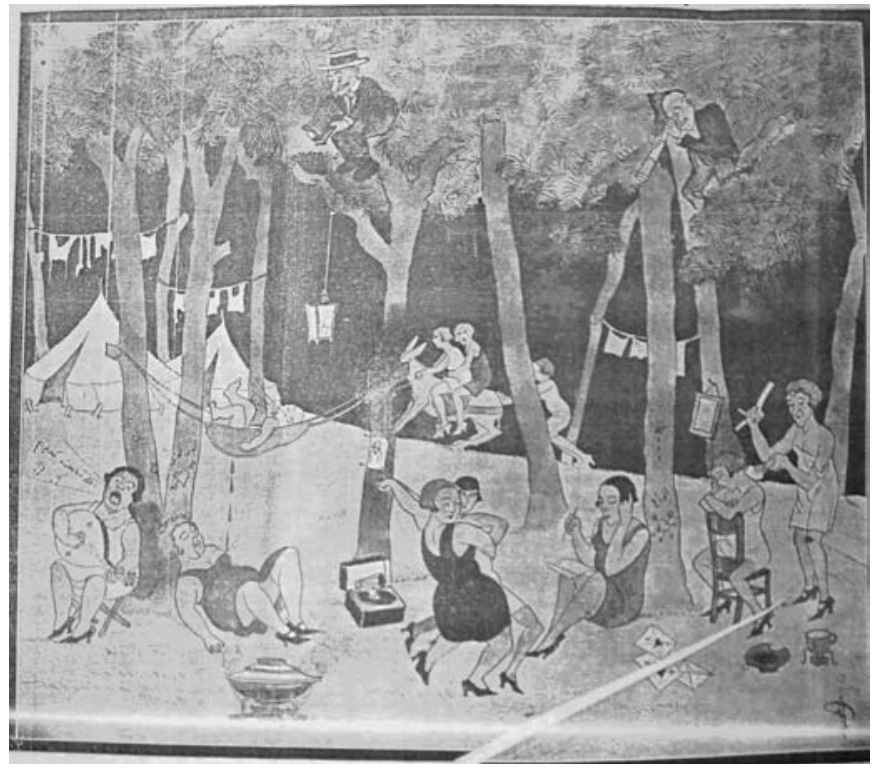

Cómo pasan el tiempo nuestras mujeres en los chames de Halkii.

$4^{35}$ ] núm. XIX/26 (martes 2 elul 5687 - 30 agosto 1927)

La carne en el gancho

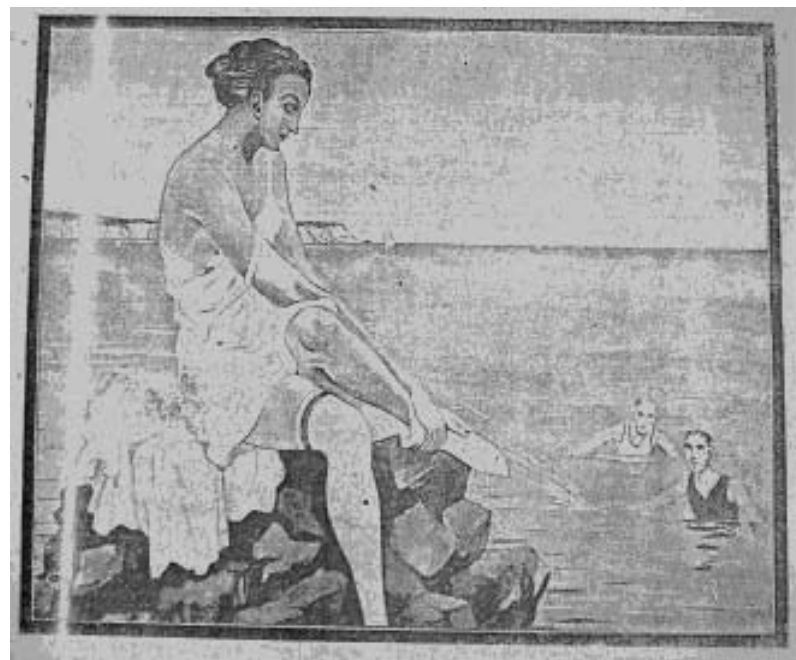

${ }^{34}$ Publicada en Romero, $Y$ hubo luz, pág. [321], sólo se reproduce allí la ilustración.

${ }^{35}$ Publicada en Romero, Y hubo luz, pág. 178. 
5] núm. XIX/30 (29 elul 5687 - 26 septembre 1927)

\section{TIŹKÚ LEŠANIM RAḄOT}

Danses munchas, banquetas de póquer munchas, ganancias para nuestros maridos munchas.

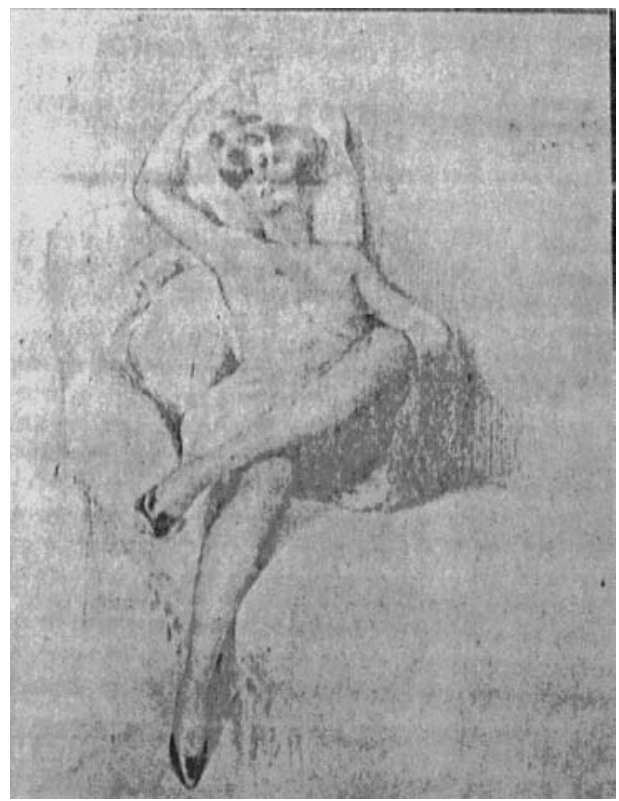

6] núm. XIX/31 (alḥad 13 tišrí 5687 [= 5688] - 9 octubre 1927)

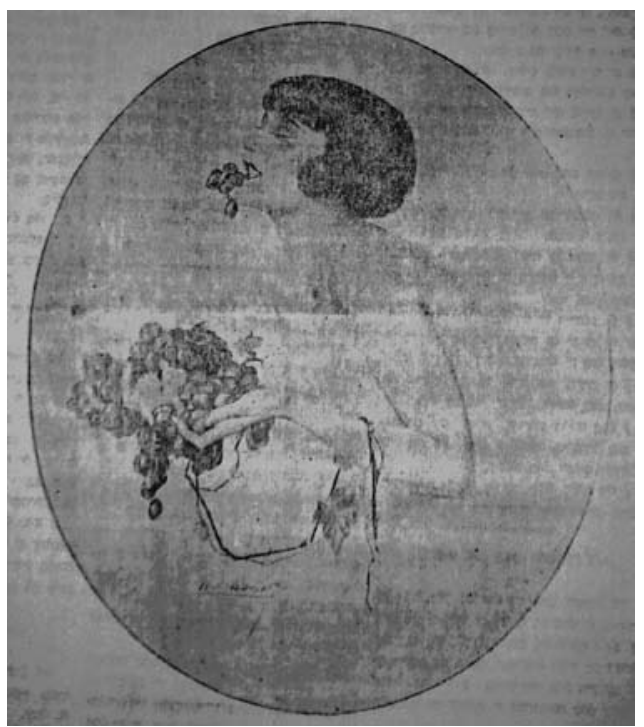

Un raćimo de uva para la suká. 
7] núm. XIX/32 (martes 29 tišrí 5687 [=5688] - 23 [=25] octubre 1927)

\section{ENTRE DOS VEĆINAS}

La una.- ¿Qué hićites medianos?

La otra.- Lo_que hago cada noche: vaćií el

portefolio del ${ }^{36}$ većino en la patisería y torní a caśa.

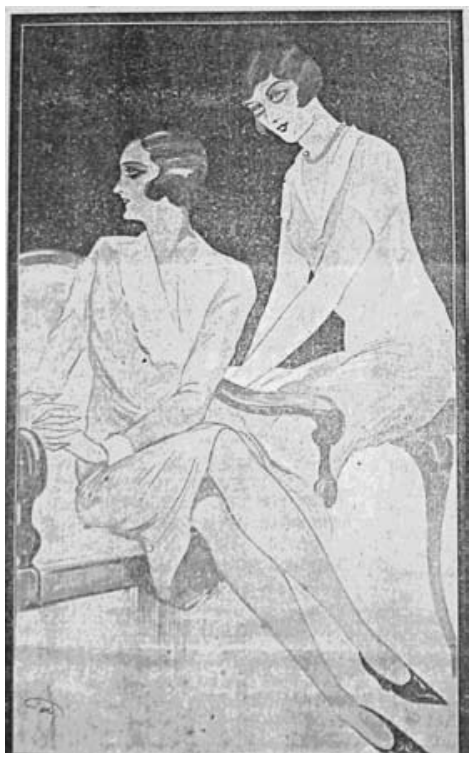

8] núm. XIX/33 (viernes 9 ḥešván 5688 - 4 novembre 1927)

\section{ENTRE PATRONA Y EMPIEGADA}

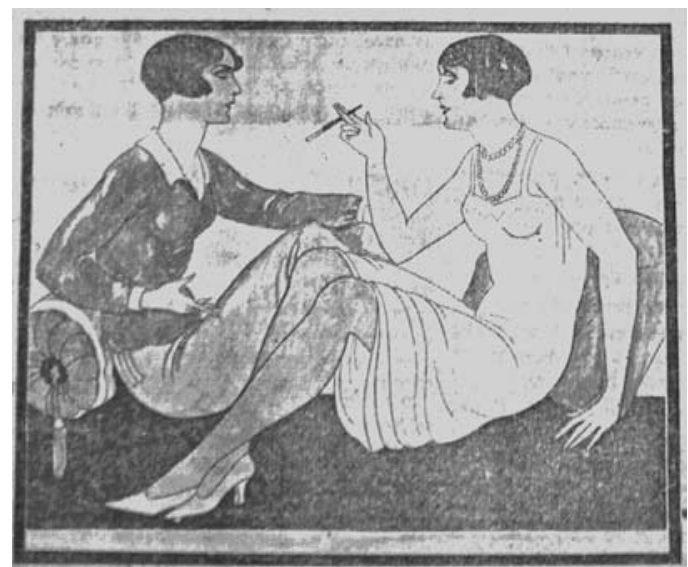

La patrona.- ¿No te demandaron viernes de ónde te mantienes?

La empiegada.- No; ya me conocieron de_la cara.

${ }^{36}$ Casi ilegible en el original. 
$9{ }^{37}$ ] núm. XIX/34 (viernes 16 ḥešván 5688 - 11 novembre 1927)

\section{CONSEJ̀O DE MADRE A HIJ̀A}

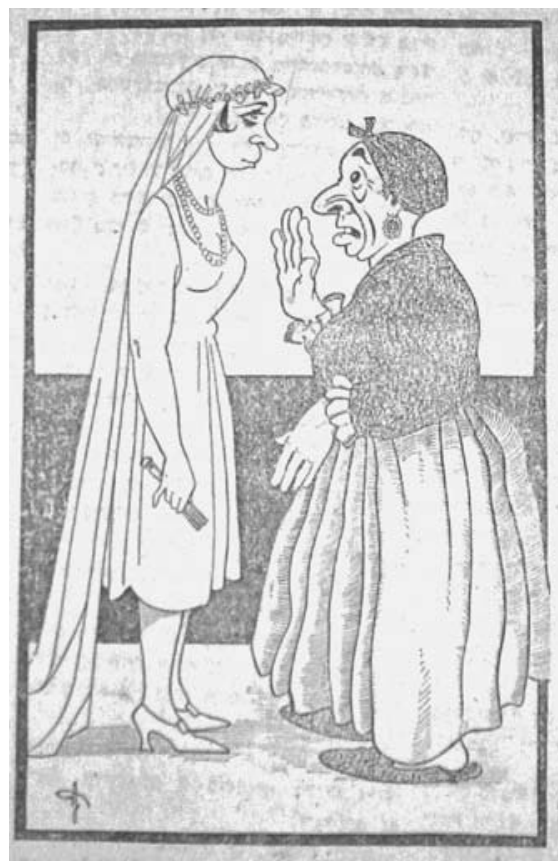

La madre.- ¡A-sí viva ${ }^{38}$ la hij̀a!

Caśar ya te vas; muncho no amostres la cara a tu marido, porque

la narićica te afea.

10] núm. XIX/35 (viernes 23 ḥešván 5688 - 18 novembre 1927)

\section{MARIDO Y [MUJ̀ER] PERA}

La mujer-- Cuando morábamos en Haskioy, este tiempo me traías bimuelos.

El marido.- En Pera no se come bimuelos, aquí es «café o lé».

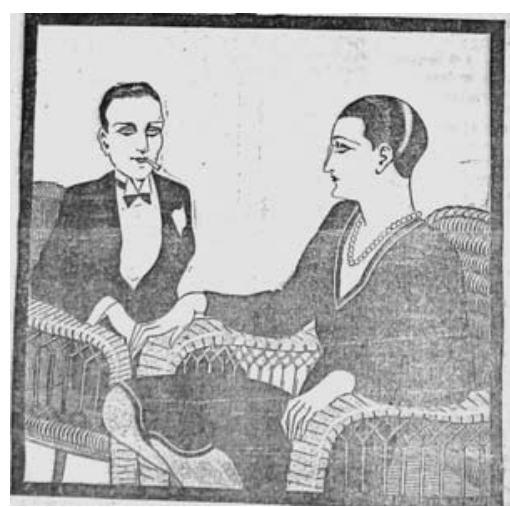

\footnotetext{
${ }^{37}$ Publicada en Romero, Y hubo luz, pág.116.

${ }^{38}$ En el original, escrito אה סי ביביה.
} 
11] núm. XIX/36 (viernes 1 kislev 5688 - 25 novembre 1927)

\section{CONVERSACIÓN ENTRE VEĆINOS AMISTOŚOS}

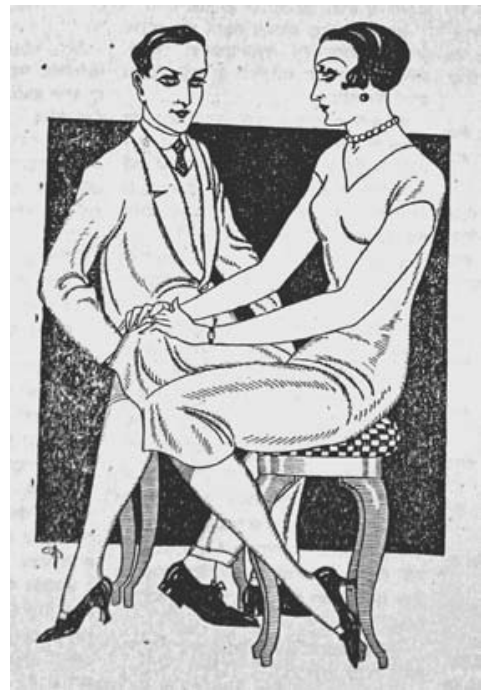

Ella.- Si me traes para Hanuká

bimuelos, para Purim te vo dar un folar.

$12^{39}$ ] núm. XIX/37 (viernes 8 kislev 5688 - 2 decembre $^{40} 1927$ )

\section{ENTRE YERNO Y ESFUEGRA}

El yerno.- Seš meśes hay que caśí: vuestra hija ya parió.

La esfuegra.- Antes de caśar vos diǰe que mi hija es chapucchía en todo modo de cośa.

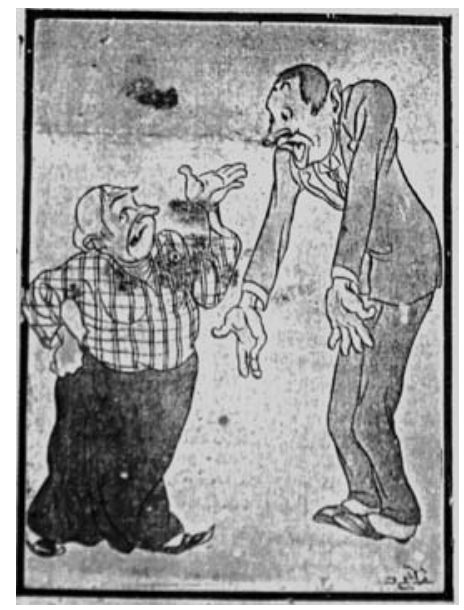

${ }^{39}$ En Romero, Y hubo luz, pág. [288] se reproduce entera la portada de este número pero no se edita el texto.

${ }^{40}$ Corrijo la forma dciembre del original; passim. 
$13^{41}$ ] núm. XIX/38 (viernes 15 kislev 5688 - 9 decembre 1927)

\section{ENTRE MARIDO Y MUJ̀ER}

El marido.- Dos bilietos tengo para el teatro; ¿queres venir?

La mujer.- Es bien seguro.

El marido. -Alora, empézate a vestir; fin mañana la noche que vamos a irmos al teatro, viene carar de vestirte.

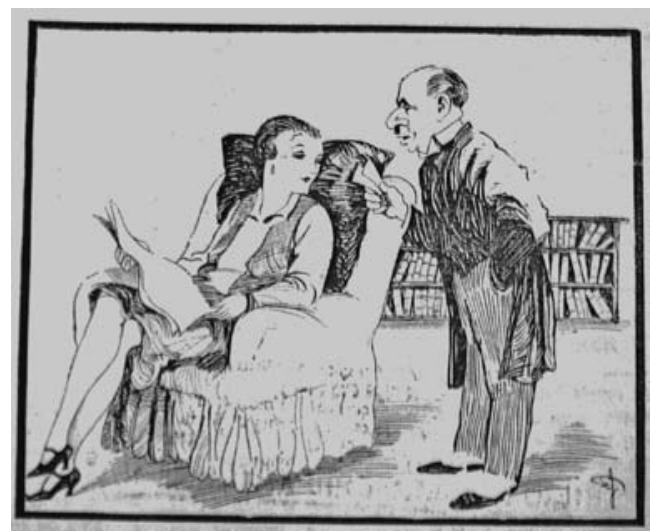

$14^{42}$ ] núm. XIX/39 (viernes 22 kislev 5688 - 16 decembre 1927)

\section{LOS GATOS EN LA DANS}

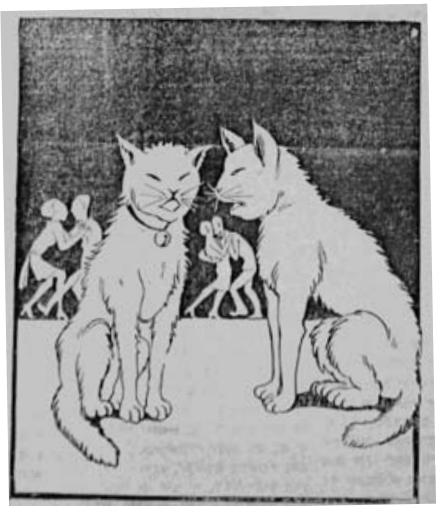

La gata.- Las personas están bailando cada día; y nośotros ¿cuándo vamos a bailar? El gato.- Ten pacencia; para mart y nośotros bailamos ${ }^{43}$.

${ }^{41}$ En Romero, $Y$ hubo luz, pág. 245 se reproduce entera la portada de este número pero no se edita el texto.

${ }^{42}$ En Romero, $Y$ hubo luz, pág. [288] se reproduce entera la portada de este número pero no se edita el texto.

${ }^{43}$. Se refiere a la época de celo de los gatos, y parece parodiar los achuchados y procaces bailes modernos. 
$15^{44}$ ] núm. XIX/41 (viernes 6 tebet 5688 - 30 decembre 1927)

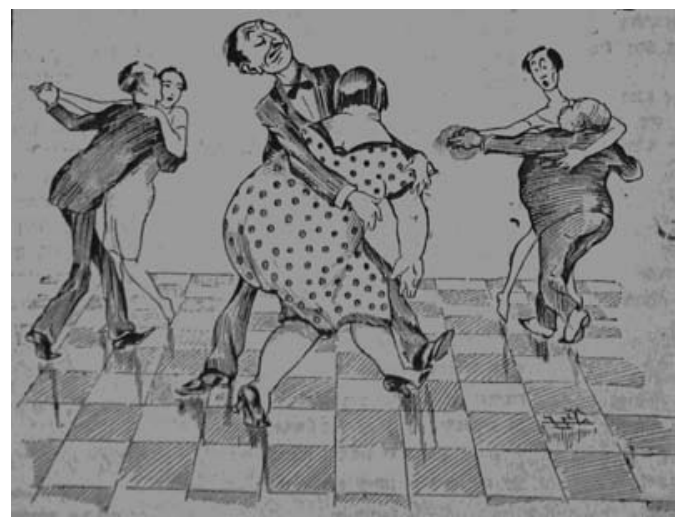

Cómo bailaron algunos nicochiris de_los nuestros la noche de Noel, en el balo.

$16^{45}$ ] núm. XIX/49 (viernes 3 adar 5688 - 24 feḅrayo 1928)

CONVERSACIÓ[N] EN EL BALO

El joven.- Madmuaśel, es por la cuatrena vez que venís con el mismo ${ }^{46}$ vestido al balo.

La demuaśel.- Con el mismo vestido ya se puede venir cuatro većes, ma con el mismo cavalier no se puede bailar.

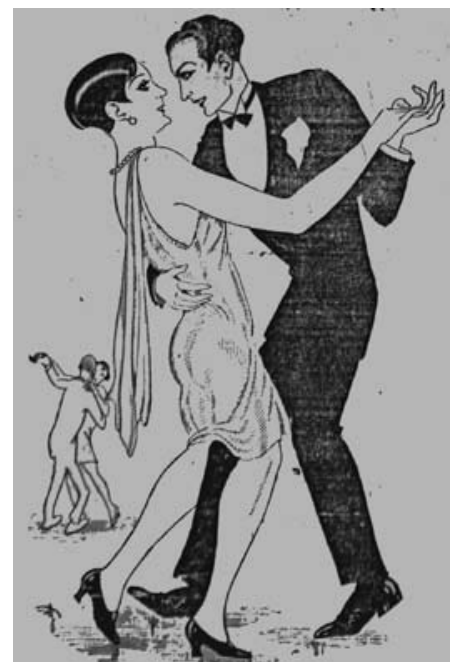

${ }^{44}$ Publicada en Romero, $Y$ hubo luz, pág. 270, se prefiere allí la lectura nicocheres. Sigo la vocalización propuesta en Max. L. Wagner, Beiträge zur kenntnis des Judenspanischen von Konstantinopel (Wien, 1914), p. 63.

${ }^{45}$ En Romero, $Y$ hubo luz, pág. 269 únicamente se reproducen la viñeta y su título original aljamiado.

46 En el original, escrita con sámej en lugar de źayin. 
$17^{47}$ ] núm. XX/2 (martes 21 adar 5688 - 13 marzo 1928)

\section{ĜILVÉS DE VEĆINDARIO}

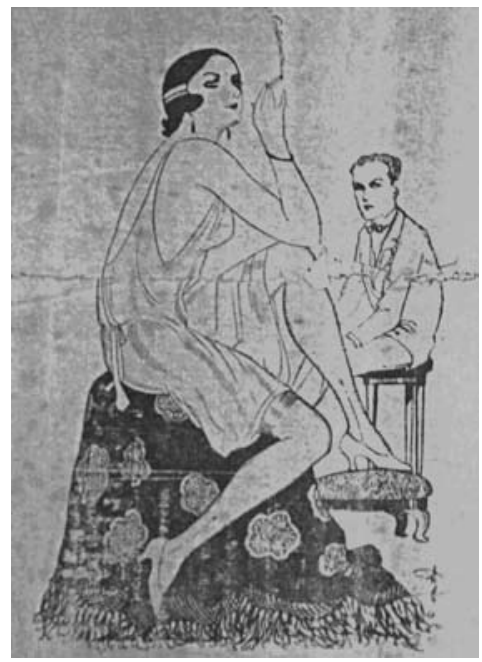

El većino.- Mañana la noche es mi aniversario, ¿qué me vas a dar de regalo?

La većina.- Dame cien liras de purimlic, ya te hago un regalo de diez liras.

$18^{48}$ ] núm. XX/4 (martes 6 nisán 5688 - 27 marzo 1928)

LO QUE PASA EN ESTOS DÍAS EN ALGUNAS CAŚAS

La mujer.- Por esta luź del Dio, si no me mercáš locza nueva, noche de Pésạ̣ vo lo vo dar de preto.

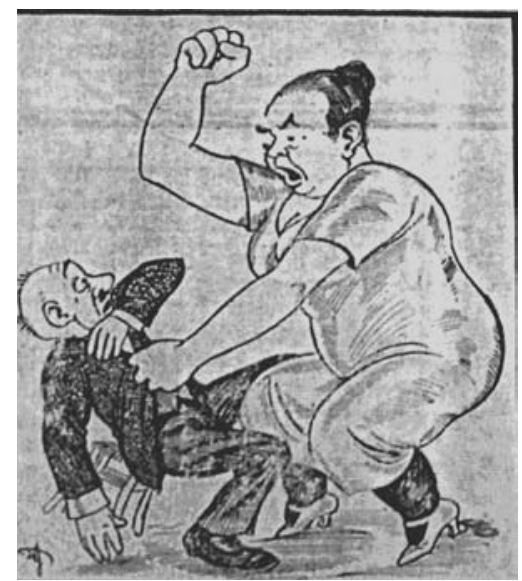

${ }^{47}$ En Romero, Y hubo luz, pág. 117 únicamente se reproducen la viñeta y su título original aljamiado.

${ }^{48}$ Publicada en Romero, $Y$ hubo luz, pág. 135, se prefiere la transcripción locsa para el original לוקסה. 
$19^{49}$ ] núm. XX/5 (martes 13 nisán 5688 - 3 abril 1928)

\section{EL HIJ̀O DEL CHELEBÍ Y LA MOZA}

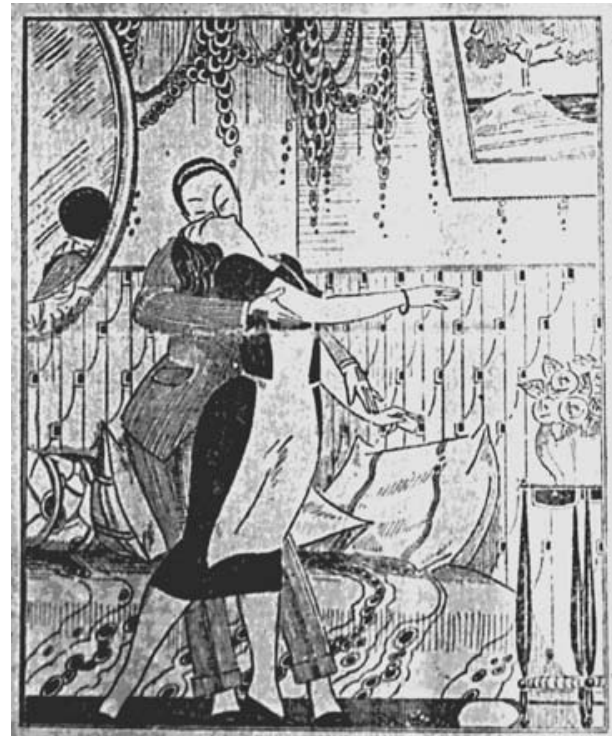

El joven.- Si me amas de corazón, te vo haćer señora de caśa.

La moza.- No quero ser nunca señora; nunca puedría rec[i]bir yo las duras palabras de una servidera.

$20^{50}$ ] núm. XX/11 (jueves 5 siván 5688 - 24 mayo 1928)

\section{MO`ADIM LESIMḤÁ}

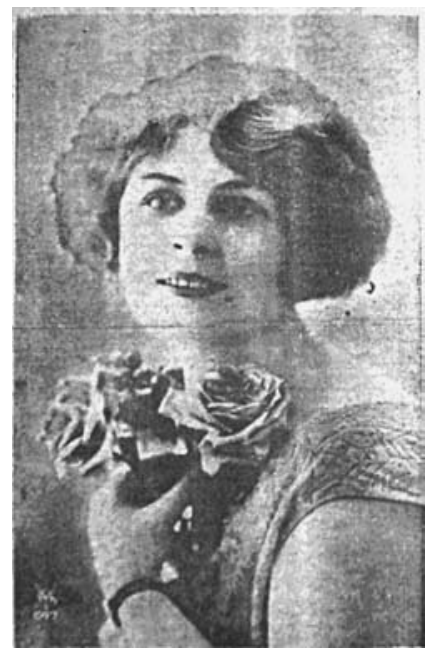

${ }^{49}$ Publicada en Romero, Y hubo luz, pág. 283.

${ }^{50}$ En Romero, $Y$ hubo luz, pág. 202 se reproducen la viñeta y su subtítulo original aljamiado. 
21] núm. XX/14 (viernes 27 siván 5688 - 15 junio 1928)

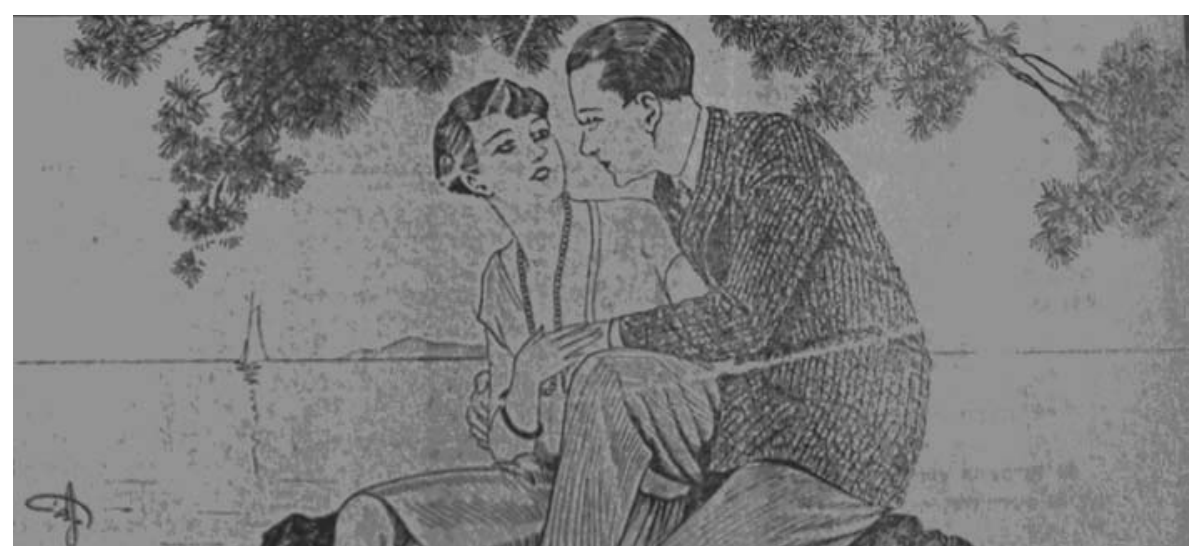

Novio y novia haćiendo «šehehẹeyanu» en los chames de Prinkipó.

$22^{51}$ ] núm. XX/15 (viernes 4 tamuź 5688 - 22 junio 1928)

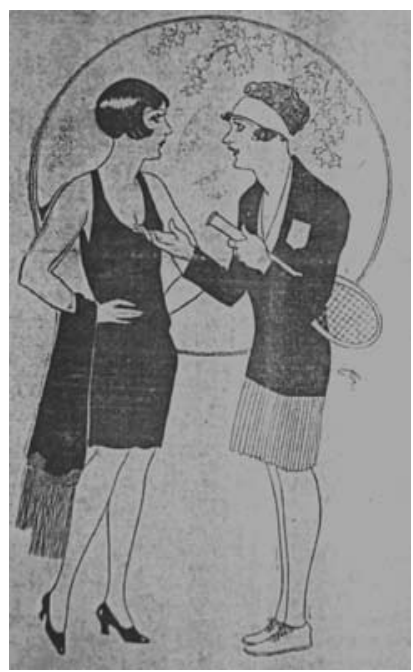

ENTRE DOS AMIGAS

La de la paleta.- ¿Queres bien a tu novio?

La otra.-Aínda no te puedo dećir. Esta tadre me prometió que me va traer un fustanlic de crep floresán ${ }^{52}$; si lo trae, puede $\mathrm{s}[\mathrm{e}] \mathrm{r}$ lo empezo a querer bien.

${ }^{51}$ En Romero, $Y$ hubo luz, pág. 256 únicamente se reproducen la viñeta y su título original aljamiado.

${ }^{52}$ Prefiero la lectura floresán (y no florisán) entendiendo que nos encontramos ante la voz turca floresan 'fluorescente' tomada del francés florissant 'resplandeciente, brillante'. En cualquier caso, y dado el contexto, no sería impensable considerar que estuviéramos ante la adaptación judeoespañola del fr. fleurissant 'florido, floreado' 
23] núm. XX/16 (viernes 11 tamuź 5688 - 29 junio 1928)

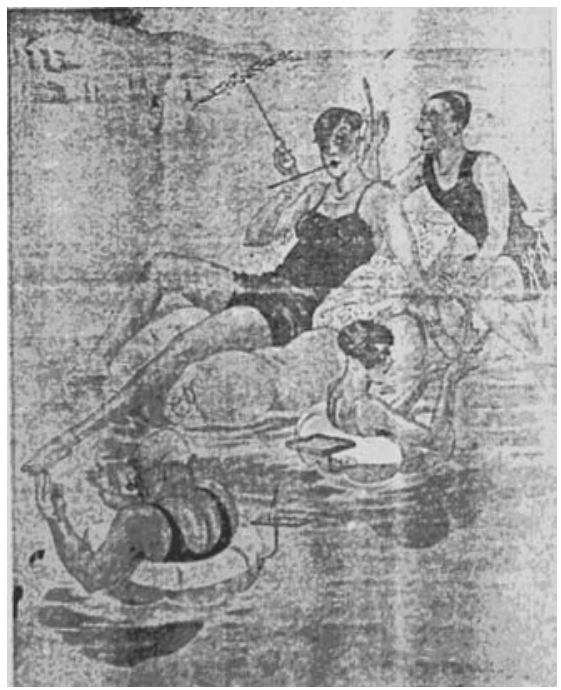

Cómo haćen la tualeta adientro los baños.

24] núm. XX/18 (viernes 25 tamuź 5688 - 13 lulio 1928)

\section{EL VIEJ̀O Y LA MAIMONA ${ }^{53}$}

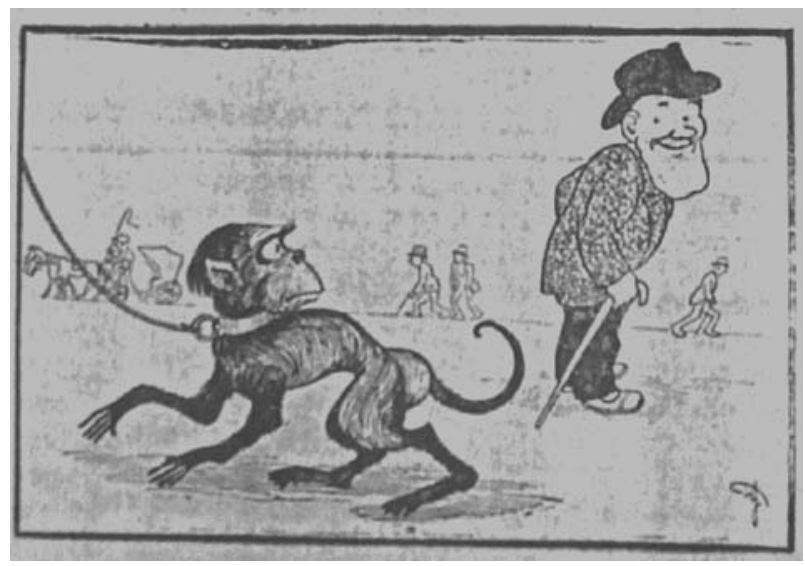

Véase conversación en la segunda hoja.

${ }^{53}$ Prefiero la vocalización con [o] sobre la base del arabismo del español maimón y siguiendo a Nehama (Dictionnaire, s.v. maymón), aunque no puede descartarse en este caso una mayor influencia de la forma turca maymun,-a, a la hora de determinar el timbre de la vocal velar. De hecho, como gentilmente me avisa la Dra. Dora Mancheva, en textos como el vocabulario en cirílico de Daniel Mefanov (pág. 65, lín. 38) leemos s.v. singe fr. маймуна bg. маймуна sef., donde el uso de $<y>$ en cirilía nos indica claramente su valor de [u]. 
$25^{54}$ ] núm. XX/22 (viernes 1 elul 5688 - 17 agosto 1928)

\section{LA NUEVA SERVIDERA Y LA BALABAYA}

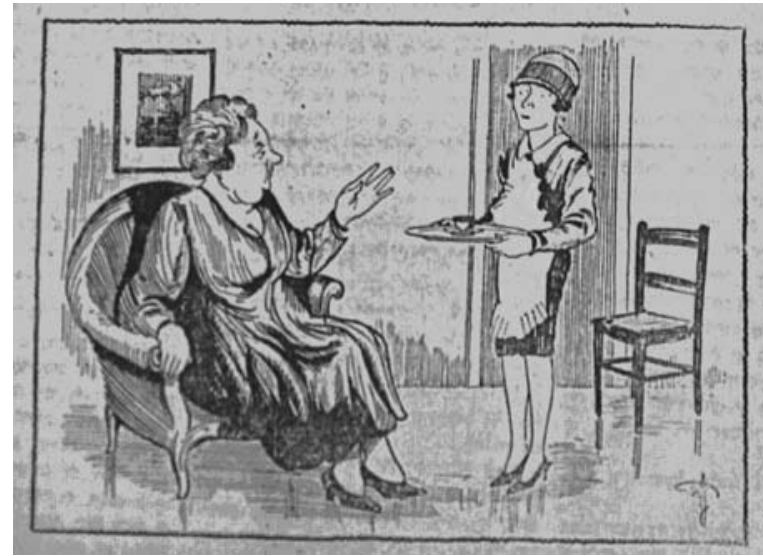

La balaḅaya.- ¿De qué estás sirviendo con chapeo?

La servidera.- No sé cuántos puntos vo quedar aquí.

$26^{55}$ ] núm. XX/23 (viernes 8 elul 5688 - 24 agosto 1928)

\section{LOS BAILES DE AGORA}

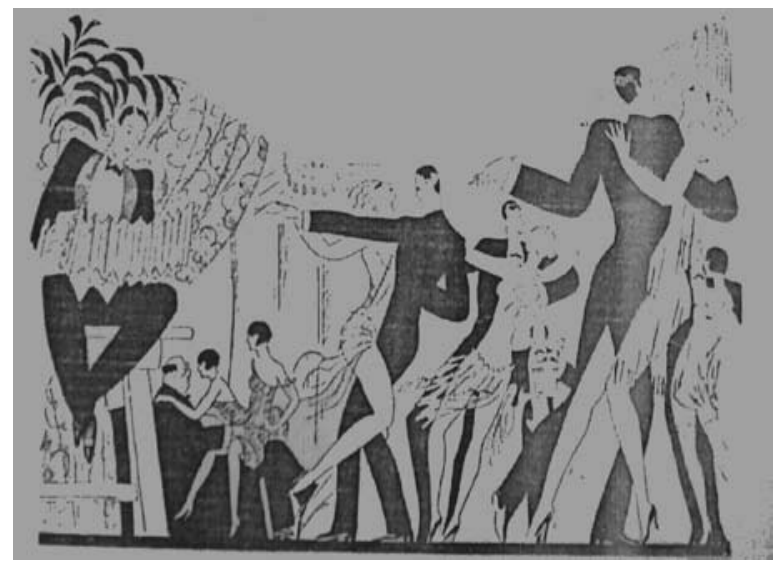

${ }^{54}$ Publicada en Romero, Y hubo luz, pág. 281, se reproduce allí también la aljamía original.

${ }^{55}$ En Romero, Y hubo luz, pág. 272 se reproducen la viñeta con el texto aljamiado inserto en ella. 
27] núm. XX/24 (viernes 15 elul $5688-31$ agosto 1928) ${ }^{56}$

ENTRE DOS AMIGAS

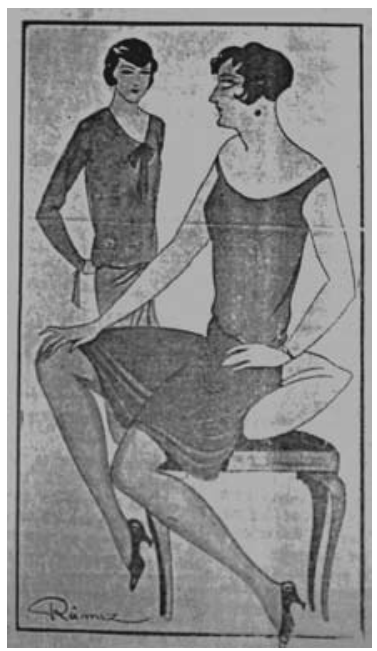

La una.- ¿Te estás emỵeźando las escrituras latinas?

La otra.- Ya me las emveccí y estó muy contente. Cuando me viene alguna carta, la mamá no sabe meldarla.

28] núm. XX/25 (viernes 22 elul 5688 - 7 septembre 1928)

\section{ENTRE DOS AMIGAS}

La del manto ${ }^{57}$.- Tú que sos tan chica, ¿te vas a caśar con un nicochiri?

La otra.- Seguro, él me está traendo cada día regalos.

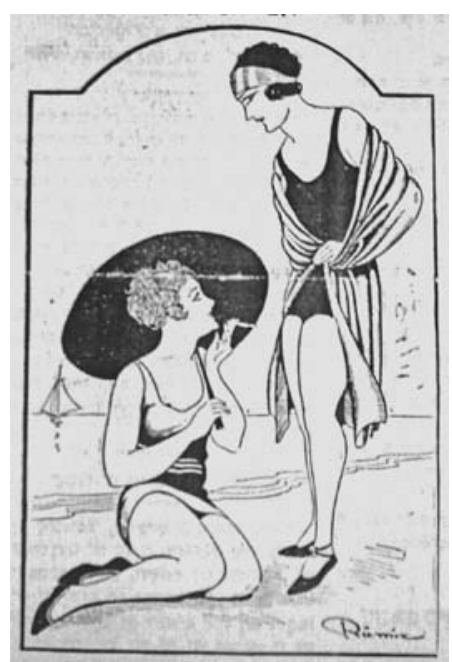

56 Vid. nota 17.

${ }^{57}$ A la vista de la imagen, prefiero la lectura manto frente al galicismo mantó (fr. manteau 'abrigo'). 
29] núm. XX/26 (viernes 29 elul 5688 - 14 septembre 1928)

\section{ENTRE DOS AMIGAS}

La del espejo.- Tengo un am[i]go probe qu[e] lo quero muncho bien; $\mathrm{y}$ un $\mathrm{r}[\mathrm{i}]$ co que me quere muncho bien. A quén que tome no sé.

La otra.- Toma al probe que ya lo queres bien, y al rico dám[e]lo a mí por regalo de capo de año.

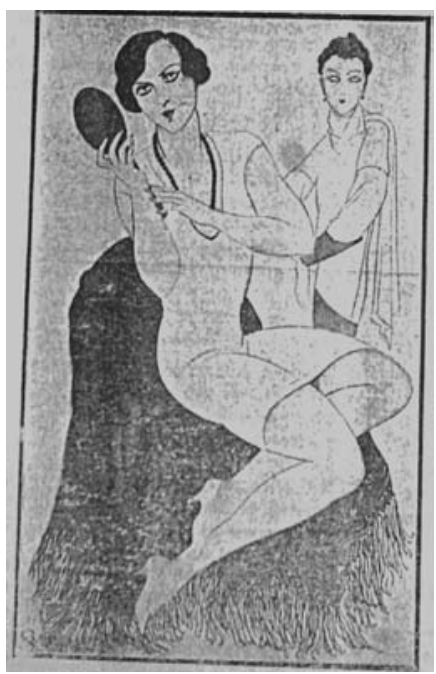

$30^{58}$ ] núm. XX/41 (viernes 22 tebet 5689 - 4 ĝenayo 1928 [=1929])

\section{ENTRE MARIDO Y MUJ̀ER}

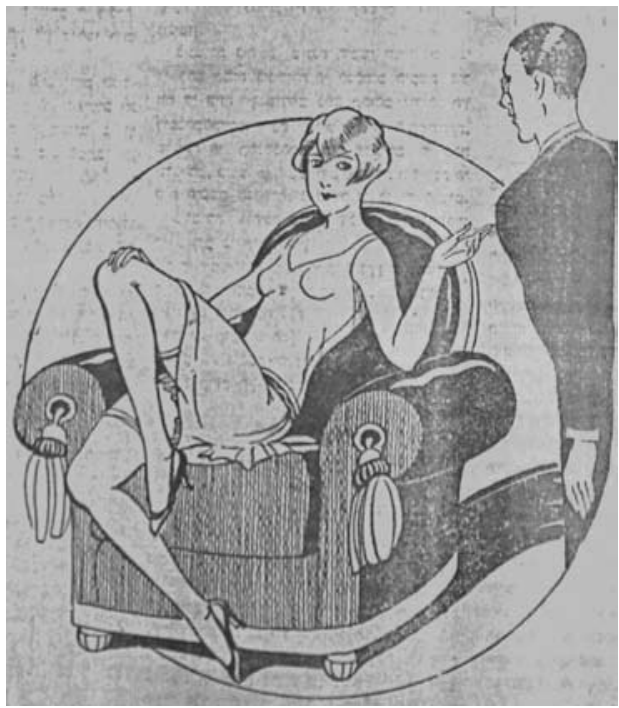

El marido.- Tres días hay que me cayó el botón del pantalón, aínda me lo tienes que cuśir. La mujer-- ¿Cómo que te lo cuśga? A medio-día me levanto de dormir, como un bocado, ya quero repośar. ¿Qué hora tengo?

${ }^{58}$ Publicada en Romero, Y hubo luz, pág. 253. 
$31^{59}$ ] núm. XX/42 (viernes 29 tebet 5689 - 11 ĝenayo 1928 [=1929])

\section{LA NUEVA DANS, BAILADA POR 4 PERSONAS}

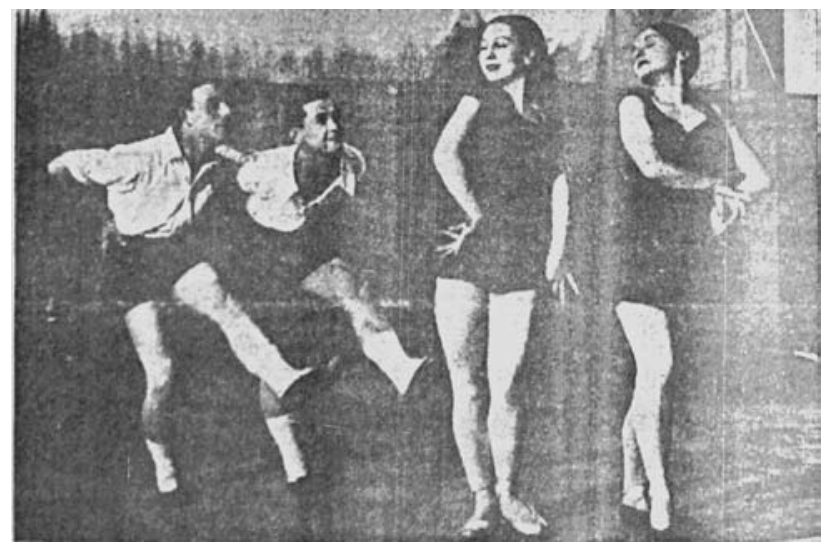

[E]sta nueva dans que veš aquí arriba nos está viniendo de_la Alemania. Anque los alemanes tienen muncha experienza en la dans, este baile es bien viejo y se bailaba antes 50 años con el nombre dans minué. Del Arcadáš

$32^{60}$ ] núm. XX/43 (viernes 6 šebat 5689 - 18 ĝenayo 1928 [=1929])

\section{SUSPIRO DE UNA DEMUAŚEL}

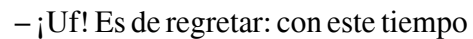
yelado y luviośo no puedo abrir la ventana para saludar al većino.

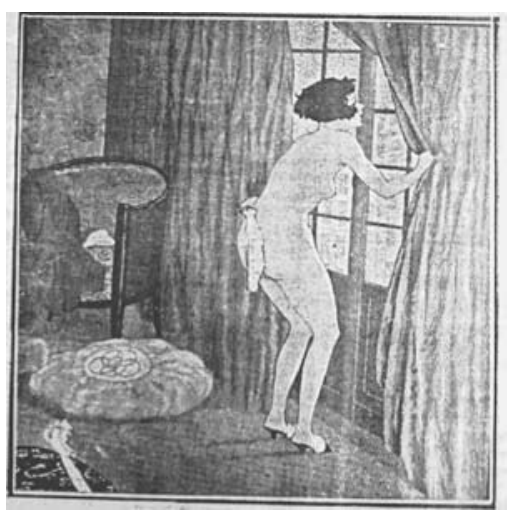

${ }^{59}$ Publicada en Romero, Y hubo luz, pág. 253, se reproduce allí la portada entera de este número pero no se incluye la referencia al periódico turco del que está tomada la ilustración. Por otro lado preferimos la transcripción dans (y no danz, como allí se lee) del original דאנס, para resaltar el origen francés de la palabra.

${ }^{60}$ Publicada en Romero, Y hubo luz, pág. 162, se ha deslizado allí la errata lluviośo para el original לובייוזי 
33] núm. XX/46 (viernes 5 adar 5689 - 15 febrayo 1929)

\section{LA NIEVE DE ESTOS DÍAS}

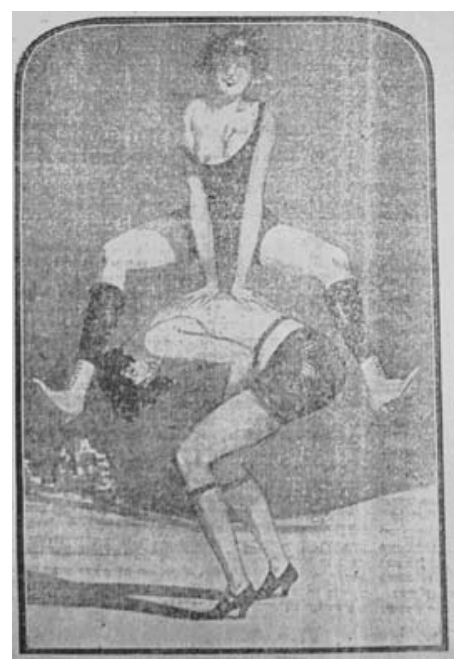

Las mancebas no sienten frío.

$34^{61}$ ] núm. XX/47 (viernes 12 adar 5689 - 22 febrayo 1929)

\section{SUSPIRO DE REĆÉN CAŚADO}

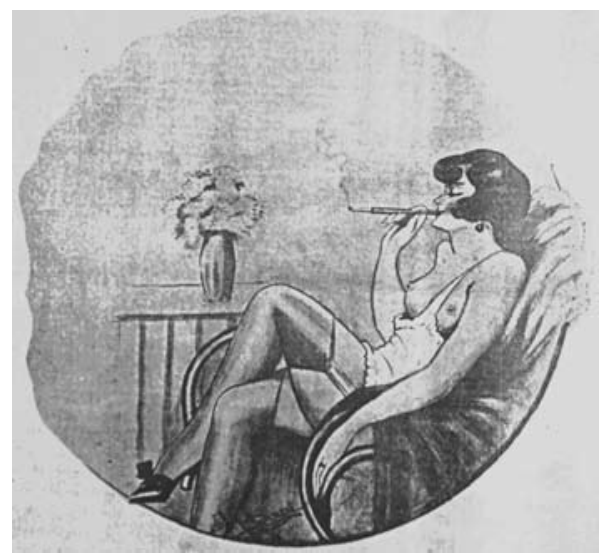

Mi marido me arrabia que me alevanto a_las 11: no haće cuento que avanza dos soḅás de leña en este tiempo de carestía.

${ }^{61}$ En Romero, $Y$ hubo luz, pág. 272 únicamente se reproducen la viñeta y su título original aljamiado. 
$35^{62}$ ] núm. XX/50 (viernes 10 veadar 5689 - 22 marzo 1929)

\section{ENTRE MARIDO Y MUJ̀ER}

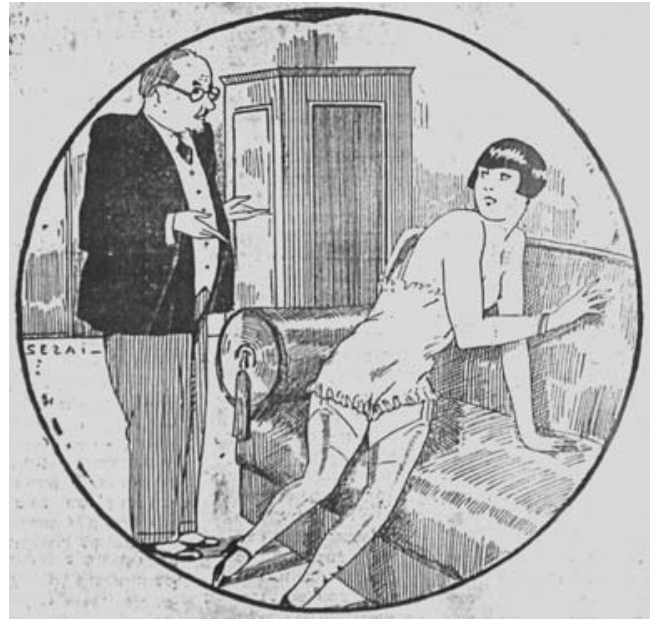

El marido.- No estó entendiendo este capricho tuyo, ¿de qué no me queres haćer folar este šaḅat que es de Purim?

La mujer.- Agora no se uśa a comer folar en caśa: es onde la većina.

36] núm. XXI/1 (viernes 17 veadar 5689 - 22 [=29] marzo 1929)

\section{ENTRE MARIDO Y MUJ̀ER}

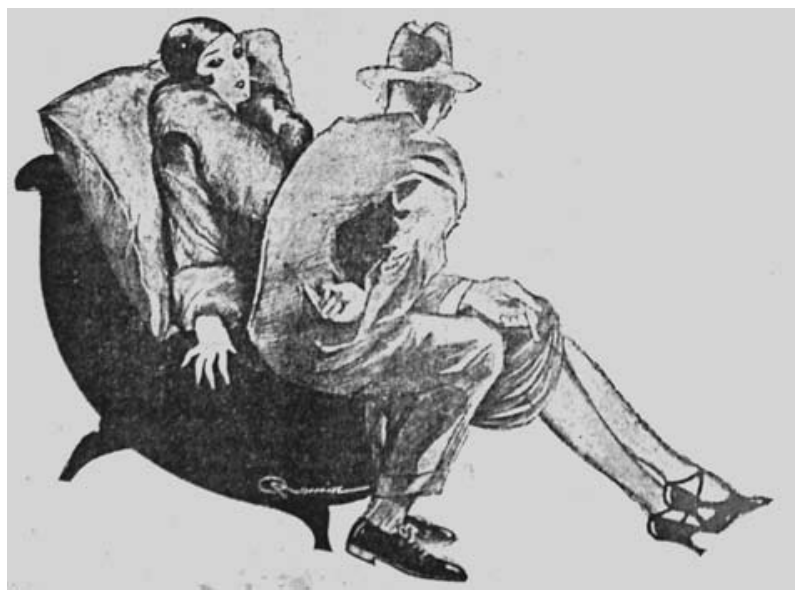

La mujer-- Una lira te demandí; me estás haćiendo mutra. Si eras bequiar, agora ibas a dar diez de geźá.

${ }^{62}$ En Romero, $Y$ hubo luz, pág. [288] se reproduce entera la portada de este número pero no se edita el texto. 
$37^{63}$ ] núm. XXI/5 (viernes 7 iyar 5689 - 17 maís 1929)

\section{ENTRE DOS AMIGAS}

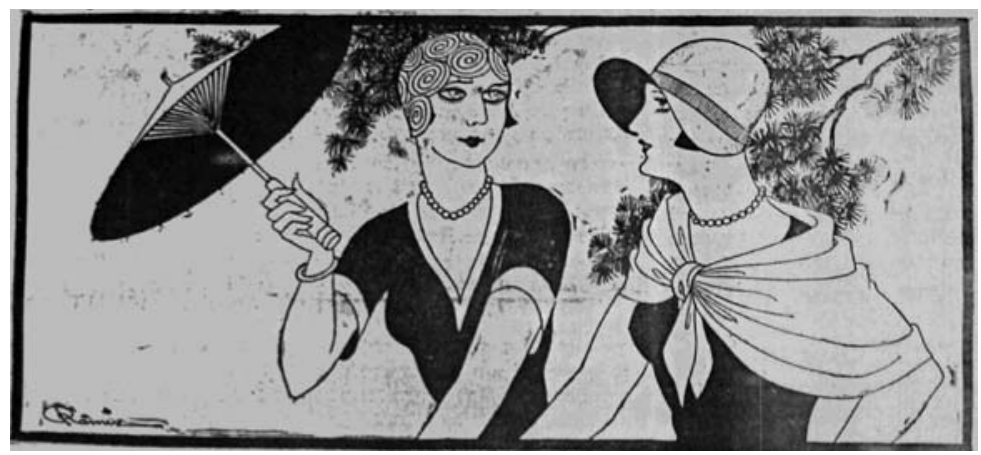

La del chapeo.- ¿Con quén estás este año en Prinkipó?

La otra.- Con mi amante.

- ¿Quén es tu amante?

- Aínda no sé.

$38^{64}$ ] núm. XXI/6 (viernes 14 iyar 5689 - 24 maís 1929)

\section{ENTRE DOS AMIGOS}

El del chapeo.- Bosteźando estás J̀ac, ¿qué te aconteció?

El otro.- Después que no dormí anoche, me soyidearon.

- ¿Ladrones?

- No, la većina.

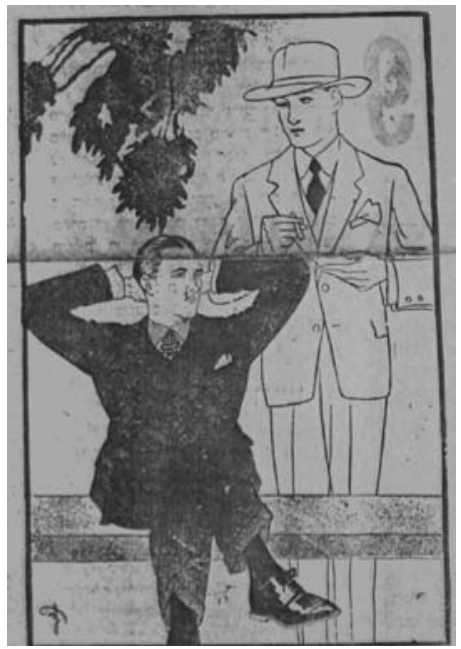

${ }^{63}$ Publicada en Romero, Y hubo luz, pág. 264.

${ }^{64}$ Publicada en Romero, $Y$ hubo luz, pág. 150, se reproduce allí la portada entera de este número. 
$39^{65}$ ] núm. XXI/7 (viernes 21 iyar 5689 - 31 maís 1929)

\section{ENTRE MARIDO Y MUJ̀ER}

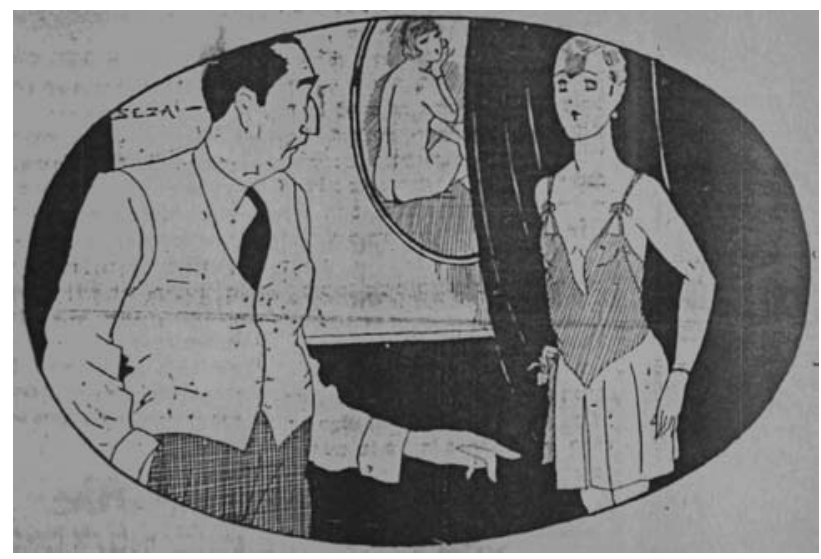

El marido.- Este costum que estrenates está muy carré.

La mujer-- Este año cale alargar la fusta; por no haćer gaste demaśía de ropa, abrí más demaśía por_arriba.

$40^{66}$ ] núm. XXI/9 (jueves 5 siván 5689 - 13 junio 1929)

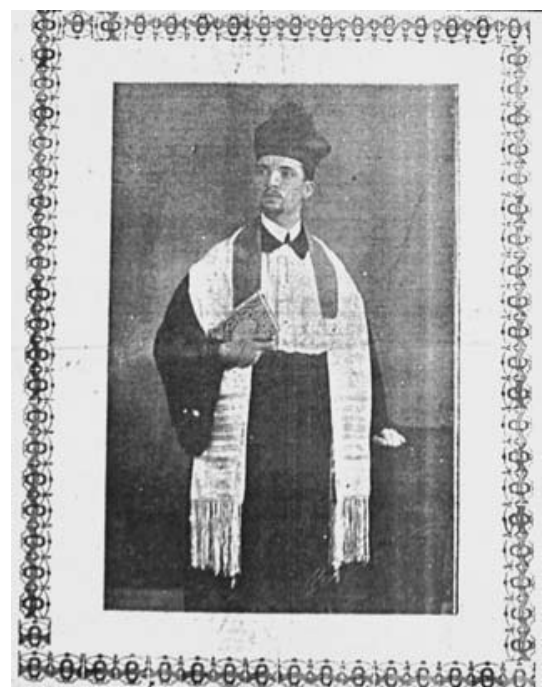

RIḄÍ ŠIM'ÓN ŠEMUEL 'UŹIEL El nuevo h’̣ del oratorio Kenéset Yisrael de Gálata.

${ }^{65}$ Publicada en Romero, Y hubo luz, pág. 111.

${ }^{66}$ En Romero, $Y$ hubo luz, pág. 258 se reproduce entera la portada de este número pero no se edita el texto. 
41] núm. XXI/10 (viernes 13 siván 5689 - 22 junio 1929)

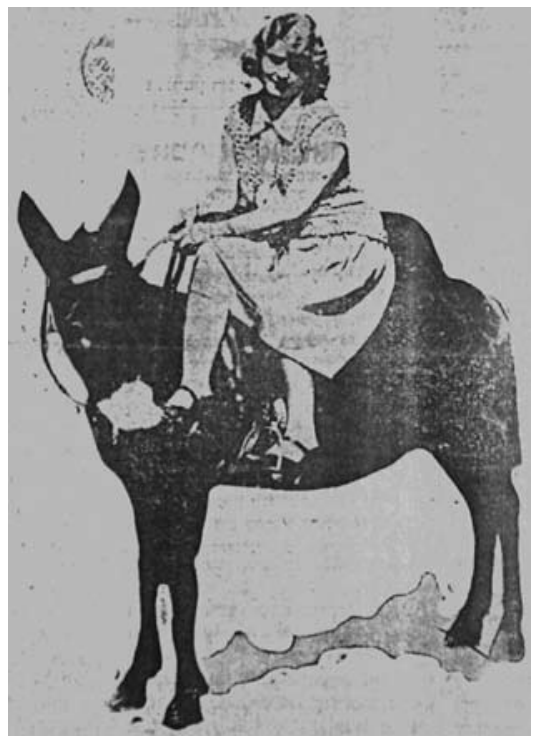

Una demuaśel de Prinkipó que ya empezó a subirse encima del aśno por pasearse.

$42^{67}$ ] núm. XXI/18 [=13] (lunes 21 tamuź 5689 - 29 lulio 1929)

El aśno.- ¡Cuántas personas deśearían a haćersen aśno como mí, en la pośición que me topo.

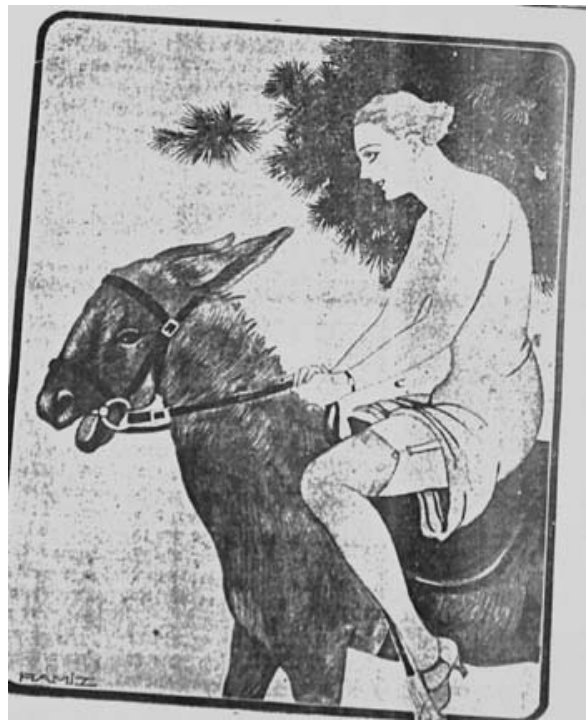

${ }^{67}$ Publicada en Romero, Y hubo luz, pág. 257. 
43] núm. XXI/15 (viernes 10 ab 5689 - 16 agustos 1929)

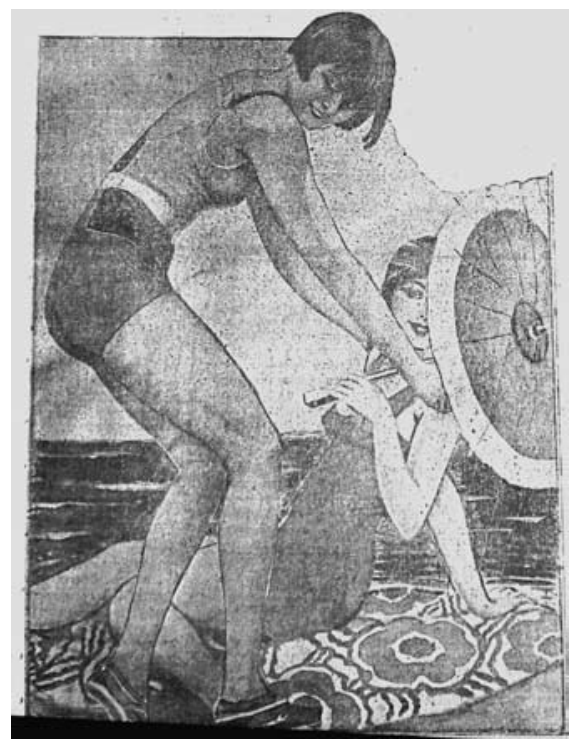

$44^{68}$ ] núm. XXI/16 (viernes 17 ab 5689 - 23 agustos 1929)

\section{PASEOS MODERNOS}

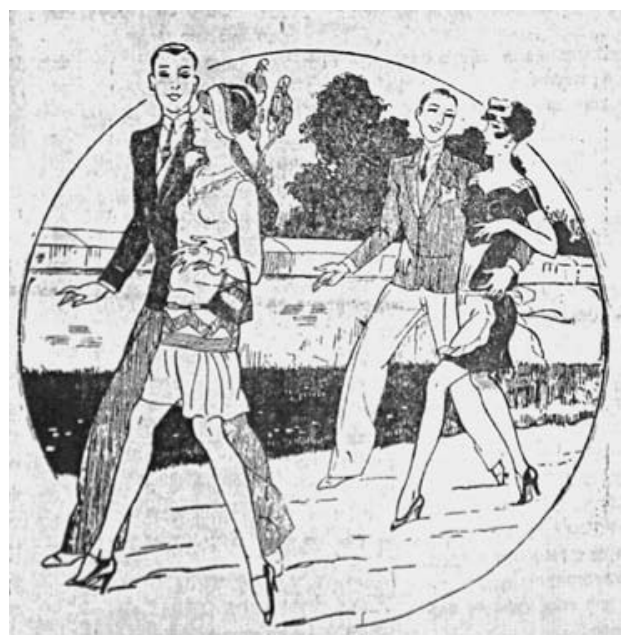

El hijo del cheleḅí con la moza, la hija del chelebíí con el hermano de_la moza.

${ }^{68}$ Publicada en Romero, Y hubo luz, pág. 275. 
45] núm. XXI/17 (viernes 24 ab 5689 - 30 agustos 1929)

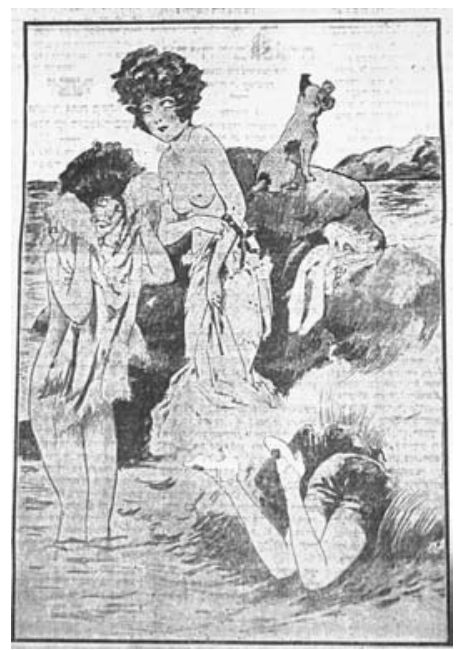

46] núm. XXI/18 (viernes 1 elul 5689 - 6 septembre 1929)

\section{ENTRE MARIDO Y MUJ̀ER}

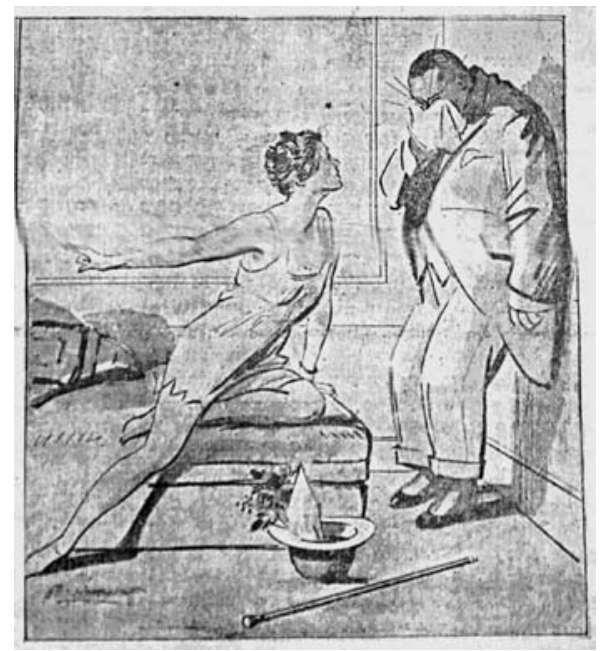

La mujer-- Tanto jugar, ya ${ }^{69}$ pedrites todo.

El marido.- Quen piedre en jugar, gana en amor.

${ }^{69}$ Corrijo la forma del original לייס. 
47] núm. XXI/19 (viernes 8 elul 5689 - 13 septembre 1929)

\section{ENTRE VEĆINDADO}

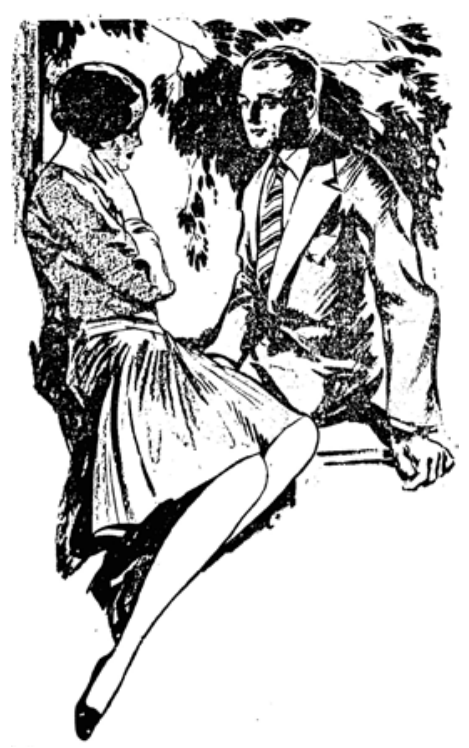

Ella.- Cuando yivía mi marido, me dećías «ten pacencia»; agora que ya se murió, ¿qué vas a dećir?

Él.-Aínda ten pacencia; y yo tengo mujer.

$\left.48^{70}\right]$ núm. XXI/20 (viernes 6 tišrí 5689 [=5690] - 10 octubre 1929)

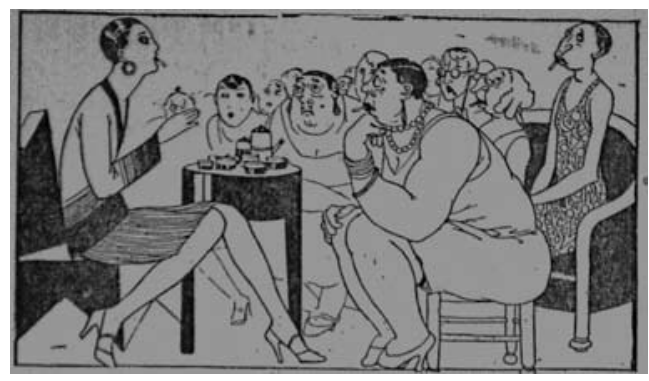

Tomadura de ta'anit

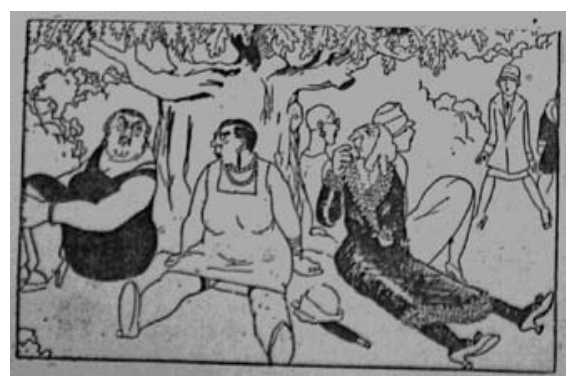

Mo'adim de un tiempo

${ }^{70}$ En Romero, $Y$ hubo luz, pág. 231 se publica únicamente la primera viñeta. 
$49^{71}$ ] núm. XXI/26 (viernes 12 ḥ̣ešván 5690 - 15 novembre 1929)

\section{ENTRE REĆÉN CAŚADOS}

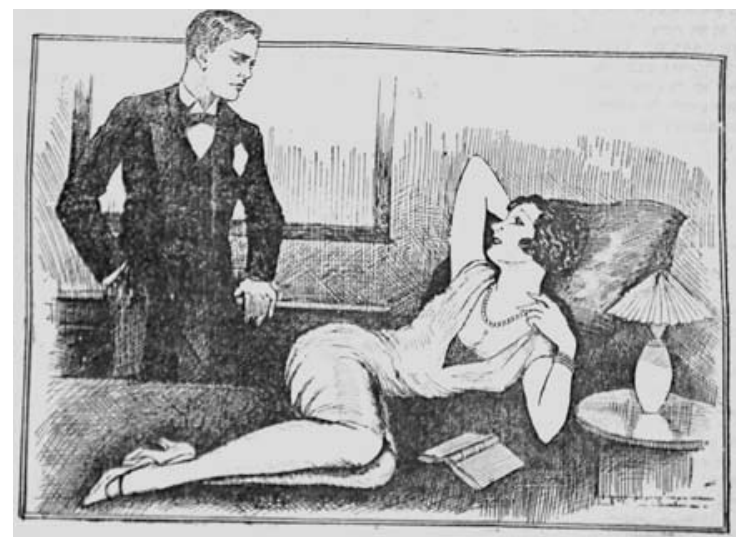

El marido.- Caśar ya caśates, y aínda no queres dejar el libro de romanzos.

La mujer.- ¿No sabes cómo los romanzos abren la gana?

50] núm. XXI/27 (viernes 19 ḥešván 5690 - 22 novembre 1929)

\section{CURA DE ESFUEÑO}

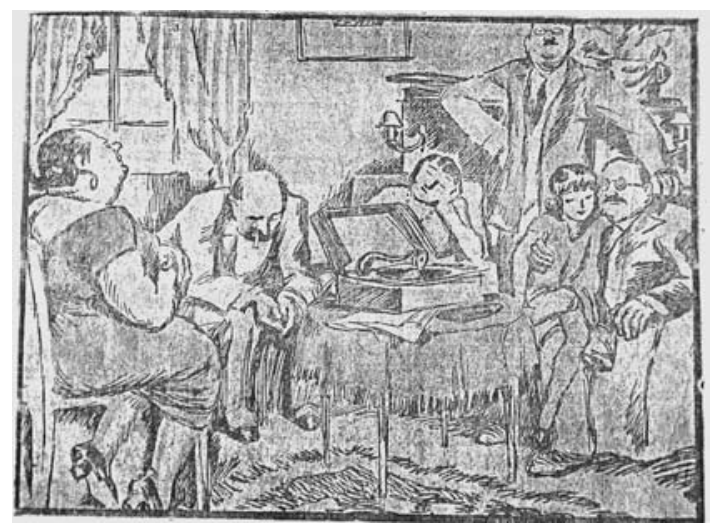

El del cigarro.- Cuando me venía desvelez, tomaba cura para dormir; agora del día que los hijos tomaron gramofón ya me estó durmiendo de suyo.

${ }^{71}$ En Romero, $Y$ hubo luz, pág. 186 se reproduce entera la portada de este número pero no se edita el texto. 
51] núm. XXI/34 (viernes 17 tebet 5690 - 17 ĝenayo 1930)

\section{ENTRE MARIDO Y MUJ̀ER}

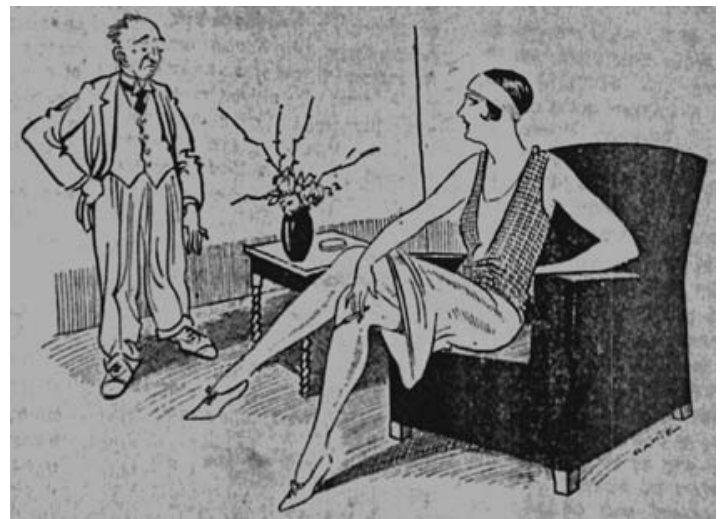

El marido.- ¿De qué estás con esta cara? ¿Qué te hiće yo?

La mujer.-Se quere cara para demandar ¿No te estás avergüenzando?

Me soñí que delantre de mí beśabas a la moza. Del Akḅaḅa

$\left.52^{72}\right]$ núm. XXI/41 (viernes 7 adar 5690 - 7 marzo 1930)

\section{ŠAḄAT DE FOLARES}

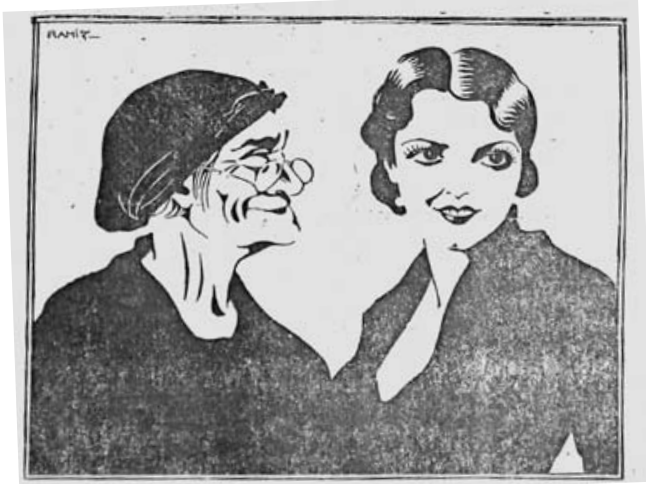

La madre.- ¡A-sí yiva ${ }^{73}$ Fortuné! Vístete que va venir tu novio y le vo dar a gustar el folar que le hicee.

La hija.- El folar tuyo no vale nada: mijor es el mío que le aparejí.

${ }^{72}$ En Romero, $Y$ hubo luz, pág. [288] se reproduce entera la portada de este número pero no se edita el texto.

${ }^{73}$ En el original, escrito אה סי ביביה. 
$53^{74}$ ] núm. XIII/13 (viernes 20 siván 5691 - 5 juunio 1931)

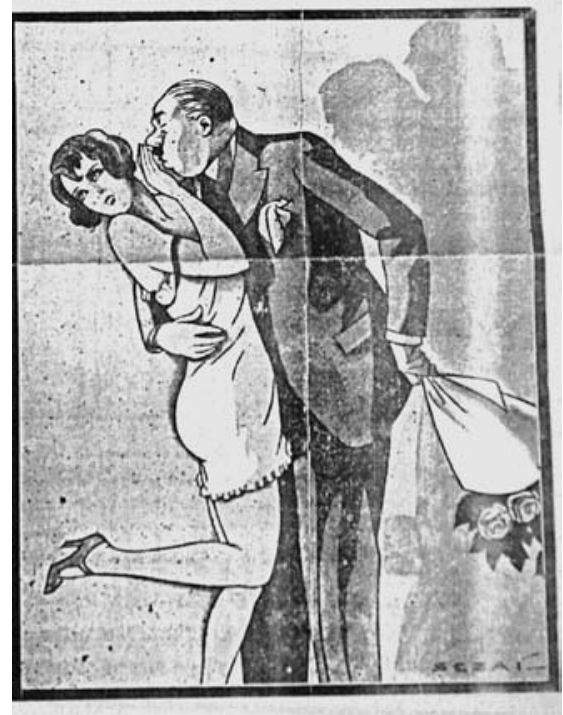

Las ĝilvés de enverano ya empezaron.

Las siguientes palabras de los textos incluidos en el presente trabajo pueden plantear dificultad de entendimiento: ab (hb. אב ): undécimo mes del calendario judío (julio-agosto).- abonamientos 'suscripciones'.- adar (hb. אדר): sexto mes del calendario judío (febrero-marzo).- agustos (tc. ă̆ustos) 'agosto'.- aínda (port. ainda) 'aína, todavía'.- alḥad: primer día de la semana judía, 'domingo'.alora (it. alora) 'entonces'.- amoḅlamiento 'mobiliario' - avanzar (it. avanzare 'sobrar') 'ahorrar'.-- balaḅaya (hb. בעלת בית + esp. -a) 'señora de la casa, ama'.balo (it. bállo) 'baile'.- bañaderas 'bañistas'.- bequiar (tc. bekâr) 'soltero'.bilietos (it. sing. biglietto) 'entradas'.- bimuelos 'buñuelos'.- bonetería (fr. bonneterie) 'mercería'. - café o lé (fr. café au lait) 'café con leche'.- capo de año (it. capo) 'año nuevo'.- carar 'bastante'.- carré (fr. carré 'cuadrado') 'escotado'.caśmires (tc. sing. kaşmir, fr. cachemire): prendas de lana de cachemir.- cavalier (tc. kavalye, fr. cavalier) 'pareja de baile'.- chames (tc. sing. çam) 'pinos'.chapucchía (tc. çabuk + tc.-cl + esp. -a) 'rápida, veloz'.- cheleḅí (tc. çelebi): 'señor, patrón' -- congeto (fr. conget, it. congedo) 'permiso, vacaciones' .-contán:

${ }^{74}$ Publicada en Romero, Y hubo luz, pág. 253, se reproduce allí la portada entera de este número. 
de — 'al contado'.- Costán: Constantinopla (Estambul).- crep (tc. krep, fr. crêpe) 'crepé' - - costum (tc. kostüm, fr. costume) 'vestido, traje'.- cuśir 'coser'.dans, pl. danses (tc. dans, fr. danse) 'baile'- dar de preto 'enfadarse mucho, montar un escándalo'.- demuasel (fr. demoiselle) 'señorita'.- elul (hb. אלול): duodécimo y último mes del calendario judío (agosto-septiembre).- empiegada (it. impiegata) 'empleada'.- encorajamiento 'estímulo, aliento'.- enỵeźarse 'aprender'.- es bien seguro (fr. c'est bien sûr) 'Por supuesto'.- escarpines (cf. $t b$. fr. escarpin) 'escarpines, zapatos'.- esfuegra 'suegra'.- esfueño 'sueño'.espor (fr. sport) 'deporte'.- fantaśís (tc. fantazi, fr. fantaisie) 'estampados, con decorado de fantasía'.- feḅrayo / febrayo (it. febbraio) 'febrero'.- fin (it. fin) 'hasta' - floresán (tc. floresán, fr. florissant) 'resplandeciente, brillante'; vid. nota 52.- folar: nombre de cierto dulce típico de la festividad de Purim, que imita la horca destinada al Amán de la historia de Ester; pero también con el sentido de órgano sexual femenino.- fusta (tc. fistan) 'falda'.- fustanlic (tc. fistan, esp. fustán) 'vestido'.- Gálata: nombre de un barrio de Constantinopla.- genayo (it. gennaio) 'enero'.- geźá (tc. ceza) 'multa'.- ĝilvés (tc. sing. cilve) 'flirteos'.gramofón (tc. gramofon, fr. gramophone) 'gramófono'.- gruš, abrev. gr. (tc. guruş, kuruş) 'piastra' - haćinos 'enfermos' .- Halkii: actual Heybeliada, una de las nueve Islas de los Príncipes, en el mar de Mármara.- hạ'n (hb. ח'ח): abrev. de hajam (hb. חכם) 'sabio, rabino', leída hă.- hạan (tc. han) 'edificio'.- Hanuká: festividad menor que comemora la purificación del Templo tras la victoria de los macabeos sobre los griegos; dura ocho días durante los cuales es preceptivo encender una lámpara de ocho candelas.- Haskioy: nombre de un barrio de Constantinopla.- Hešván (hb. חשון): segundo mes del calendario judío (octubrenoviembre).- horas: por — 'por el momento'.- iyar (hb. אייר): octavo mes del calendario judío (abril-mayo).- jartier (tc. jartiyer, fr. jarretière) 'liga'.jornal (it. giornale) 'periódico'.- kislev (hb. כסליו): tercer mes del calendario judío (noviembre-diciembre).- jugos de familia 'pasatiempos'.- lasticas (tc. lastik) 'chanclos, galochas de goma'.- lingería (fr. lingerie) 'lencería'.- liras (it. sing. lira) 'liras, libras; nombre de cierta moneda'.- locza 'loza, vajilla'.lulio (it. luglio) 'julio'.- madmuaśel (fr. mademoiselle) 'señorita, damisela'.magaśen (fr. magasin) 'almacén, tienda' - - maimona 'mona'; vid. nota 53.- maís (tc. mayıs) 'mayo'.- maladía (fr. maladie, it. malattia) 'enfermedad'.- mancar (fr. manquer, it. mancare) 'faltar'.- mantós (tc. sing. manto, fr. sing. manteau) 'abrigos'.- mart (tc.) 'marzo'.- medianos: nombre que reciben los días de media fiesta, entre el primer y último día de Pésạ̣ y de Sukot.-meldar 'leer' - mo‘adim (hb. מועדים) 'fiestas' | __ lešimhá (hb. lit. 'fiestas para alegría') 'felices fiestas': augurio que se pronuncia en varias de las grandes festividades 
religiosas judías como Pésaḥ, Šabu'ot o Sukot.- moza 'criada'.- mušamás (tc.

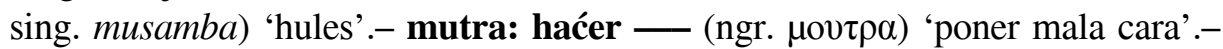

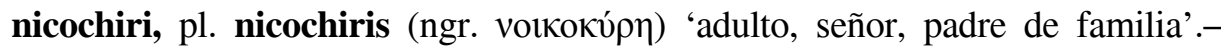
nisán (hb. ניסן): séptimo mes del calendario judío (marzo-abril).- Noel (fr. Nöel) 'Navidad'.- paleta 'raqueta'.- parás (tc. sing. para) 'monedas'.- patisería (fr. patisserie) 'pastelería'.- Pera: nombre de un barrio de Constantinopla.- perdés (tc. sing. perde) 'cortinas' .- péndola 'pluma'.- Pésaḥ: noche de ——: víspera de la Pascua, festividad de primavera que conmemora el éxodo israelita de Egipto.pišín (tc. peşin, pişin) 'al momento'.- portefolio (fr. portefeuille, it. portafoglio) 'cartera, billetera' -- presa 'prensa'.- Prinkipó: actual Büyükada, es la más grande de las nueve Islas de los Príncipes, en el mar de Mármara.- puntos 'momentos, minutos; tiempo'.- Purim (hb. פורים): festividad en la que se conmemora la salvación milagrosa de los judíos en la persia del rey Asuero, según se relata en el libro bíblico de Ester .- purimlic (hb. פורים+ tc. -lik): regalo o aguinaldo que se da a los niños durante la fiesta de Purim.- quiśac (tc. klzak) 'trineo'.- recibo 'recibimiento'.- remarcar (fr. remarquer) 'advertir, observar'.- render (fr. rendre) aquí 'hacer' -- riḅí (hb. רבי) 'rabino'.- robas (tc. sing. roba, fr. sing. robe) 'vestidos'.- romanzos (it. sing. romanzo) 'novelas'.- šaḅat (hb. שבת): último día de la semana judía; 'sábado'.- Se. abrev. de Señor.- šeheḥeyanu: faćer (hb. שהחינו, palabra clave de la bendición que se dice al probar algo): degustar o disfrutar algo por primera vez.- šebat (hb. שבט): quinto mes del calendario judío (enero-febrero).- semanada 'paga semanal'.- servidera 'sirvienta'.- sí tb. 'así' -- siván (hb. סיון): noveno mes del calendario judío (mayo-junio).- sobás (tc. sing. soba) 'estufa'.- sorte (fr. sorte) 'clase, tipo'.- šosones (tc. sing. şoson, fr. sing. chausson) 'chanclos, galochas'.- soyidear (cfr. tc. soydur) 'saquear, robar'.-- suká (hb. סוכה) 'cabañuela para la fiesta de Sukot'.- ta'anit (hb. תענית) 'ayuno'.-tamuź (hb. תמוז): décimo mes del calendario judío (junio-julio).- tebet (טבת (טבת): cuarto mes del calendario judío (diciembre-enero).- tiftiques (tc. sing. tiftik) 'mohair; cierto pelo de cabra muy fino'.- tišrí (hb. תשרי): primer mes del תזכו לשנים . calendario judío (septiembre-octubre).- tiźkú lešanim raḅot (hb) רבות, lit. 'que seáis merecedoress [de vivir] por muchos años'): augurio que se pronuncia en el año nuevo judío.- tualeta (fr. toilette, it. toletta) 'baño, higiene personal'.- turables (cfr. fr. durable) 'duraderos'.- veadar (hb. ואדר): segundo mes de adar; mes que en los años bisiestos se añade tras el mes de adar.- velures (fr. sing. velour) 'terciopelos'.- veritables (fr. sing. veritable) 'auténticos'.- $\mathbf{y}$ aquí (núms. 14 y 47) 'también'. 
